\title{
“Diş Çürüklerini Önleyici” İsimli STEM Etkinliği Hakkında Fen Bilgisi Öğretmen Adaylarının Görüşleri
}

\section{Sena Kurtoğlu $\mathbf{u}^{1}$}

\author{
Fethiye Karslı Baydere ${ }^{2}$
}

Type/Tür:

Research/Araştırma

Received/Geliş Tarihi: May 8/ 8

Mayıs 2020

Accepted/Kabul Tarihi: March

29/ 29 Mart 2021

Pagenumbers/Sayfa No: $481-509$

Corresponding

Author/İletişimden Sorumlu

Yazar: fethiyekarsli28@gmail.com

\section{$\checkmark$ iThenticate}

Thispaperwascheckedforplagiaris musingiThenticateduringtheprevi ewprocessandbeforepublication. / Bu çalışma ön inceleme sürecinde ve yayımlanmadan önce iThenticate yazılımı ile taranmıştır.

Copyright@ 2017 by Cumhuriyet University, Faculty of Education. Allrightsreserved.

\section{Öz}

$\mathrm{Bu}$ araştırmanın amacı, STEM eğitimi yaklaşımına göre geliştirilen ve fen bilgisi öğretmen adaylarına uygulanan "diş çürüklerini önleyici" isimli STEM etkinliği ile ilgili fen bilgisi öğretmen adaylarının görüşlerini incelemektir. Nitel araştırma yönteminin kullanıldığı bu araştırmanın çalışma grubunu, 2019-2020 eğitim öğretim yılında Doğu Karadeniz Bölgesi'nde bulunan bir devlet üniversitesinde öğrenim gören ve Fen Öğretimi Laboratuvarı Uygulamaları I dersini alan toplam 7 fen bilgisi öğretmen adayı oluşturmaktadır. Araştırmada veri toplama aracı olarak STEM uygulamalarıyla ilgili yarı yapılandırılmış görüşme soruları kullanılmıştır. Elde edilen veriler içerik analizi ile çözümlenmiştir. Araştırmada, "bakteriler ve diş sağlı̆̆ı" konusuna yönelik geliştirilen etkinliğin fen bilgisi öğretmen adaylarının kavramsal anlamalarını kolaylaştırdığı ve bazı 21. yüzyıl becerilerini kazanmalarına katkı sağladığı sonucuna ulaşılmıştır. Öte yandan araştırmada öğretmen adayları etkinlikle ilgili birtakım dezavantajlardan bahsetmiş olsalar da etkinliğin kendilerine çoğunlukla olumlu özellikler kazandırdığı, eğlenceli bir ortam sunarak derse karşı motivasyonlarını artırdığı, onların sürece aktif katılımına imkân sunduğu ve yaparak yaşayarak bir öğrenme sürecinde bulunmalarını sağladığı sonuçlarına ulaşılmıştır.

Anahtar Kelimeler: STEM eğitimi, tasarım temelli fen eğitimi, bakteriler, diş sağlığ1

\section{Suggested APA Citation/Önerilen APA Atıf Biçimi:}

Kurtoğlu, S., \& Karslı Baydere, F. (2021). “Diş çürüklerini önleyici” isimli STEM etkinliği hakkında fen bilgisi öğretmen adaylarının görüşleri. Cumhuriyet International Journal of Education, 10(2), 481509. http://dx.doi.org/10.30703/cije.734262

\footnotetext{
1Yüksek Lisans Öğrencisi, Giresun Üniversitesi, Fen Bilimleri Enstitüsü, Giresun/Türkiye Master Student, Giresun University, Institude of Science, Giresun/Turkey e-mail: sena.krtgl@gmail.com ORCID ID: orcid.org/0000-0002-9803-6591
}

${ }^{2}$ Doç. Dr., Giresun Üniversitesi, Eğitim Fakültesi, Matematik ve Fen Bilimleri Eğitimi Bölümü, Giresun/Türkiye Associate Prof. Giresun University, Faculty of Education, Department of Mathematics and Science Teaching, Giresun/Turkey

e-mail: fethiyekarsli28@gmail.com ORCID ID: orcid.org/0000-0003-0994-0974 


\title{
The Views of Science Teacher Candidates About STEM Activity Named "Dental Caries Inhibitor"
}

\begin{abstract}
The aim of this study is to examine the views of science teacher candidates about stem activity named"dental caries inhibitor", which was developed according to STEM education approach and applied to science teacher candidates. In this study, qualitative research method was used. The study group of the research consists of 7 science teacher candidates studying at a public university in the Eastern Black Sea region in the 2019-2020 academic year and taking the Science Teaching Laboratory Practices I course. The data of the study were collected through the semi-structured interview questions about the applications. The qualitative data were analyzed contextually. In the research, it was concluded that STEM activity developed for bacteria and dental health increased conceptual understanding of science teacher candidates and contributed to the acquisition of some $21^{\text {st }}$ century skills. In addition, although the teacher candidates mentioned some disadvantages related to the STEM activity in the research, it was concluded that the activity gave them mostly positive features such as increasing their motivation towards the lesson by providing a fun environment, enabling them to participate actively in the process and enabling them to be in a learning process by living.
\end{abstract}

Keywords: STEM education, Design based science education, Bacteria, Dental health

\section{Giriş}

Fen, teknoloji, matematik ve mühendislik alanında meydana gelen değişimler ve gelişmeler, yaşadığımız yüzyılda hayatımızı etkilemekte ve mevcut veya gelecekte karşılaşılması öngörülen sorunların çözümünde önemli rol oynamaktadır (Brophy, Klein, Portsmore ve Rogers, 2008; Bybee, 2011; National Research Council [NRC], 2012). Yaşadığımız çağın gereklerinden birisi de üreten, araştıran, sorgulayan, problem çözme becerisine sahip ve iş dünyasına adım attığında edindiği bu becerileri uygulayabilen bireylerin yetiştirilmesidir (Akgündüz, Aydeniz, Çakmakçı, Çavaş, Çorlu, Öner ve Özdemir, 2015; Çorlu ve Aydın, 2016). Günümüzde bu ihtiyaçların karşılanabilmesinde kullanılan yardımcı, yenilikçi ve bütüncül en yeni yaklaşım STEM eğitimi yaklaşımıdır (Bybee, 2011, 2013).

STEM eğitim yaklaşımı fenin, teknolojinin, matematiğin ve mühendisliğin birbirine entegre edilmesi ile oluşturulan disiplinler arası çalışmayı destekleyen güncel bir yaklaşımdır. STEM eğitim yaklaşımında fen, teknoloji, matematik ve mühendisliğin bir arada kullanılarak bireylerin günlük yaşam problemlerini çözmesi mümkündür. Nitekim bireyler bu disiplinleri birlikte kullanmaya hâkim olduktan sonra karşılaştırkları her türlü problemi kolaylıkla çözmede etkin olabilirler (Hynes, Portsmore, Dare, Milto, Rogers ve Hammer, 2011). STEM her ne kadar birden fazla alanı bünyesinde barındırsa da araştırmacılar temel olarak fen (doğa bilimleri), teknoloji, matematik ve mühendislik üzerinde durmaktadırlar (Kuenzi, Matthews ve Mangan, 2006; National Governors Association [NGA], 2007). Science (Fen), Technology (Teknoloji), Mathematichs (Matematik) ve Engineering (Mühendislik) disiplinlerinin İngilizce kelimelerinin baş harflerinin birleşimi ile oluşturulan STEM eğitimi, okul öncesinden yükseköğrenime kadar geçen süreçte disiplinler arası çalışmanın kazandırılmasında, bilgilerin soyuttan somuta dönüştürülmesinde ve günlük yaşamda karşılaşılan problemlerin çözümünde bu bilgilerin kullanılmasını esas alır (English ve King 2015; Yıldırım, 2016). Yıldırım (2013a, 2013b)'a göre STEM eğitimi, öğrencileri doğrudan öğrenmeleri için cesaretlendirir, hayallerine ulaştırır ve onların 
öğrendiklerini yeni ve farklı problemlere uygulayabilmelerini sağlar. Ayrıca STEM, ülkelerin ekonomik ve teknolojik olarak gelişmesinde etkin rol oynamakta (Bybee, 2010; National Research Council [NRC], 2011; Scott, 2009; West, 2012) ve bireyleri yaşama hazırlayıcı özelliği sayesinde son yıllarda oldukça ilgi görmektedir (Cavanagh ve Trotter, 2008).

STEM eğitimi ile ilgili yapılan çalışmalar incelendiğinde, gelişmiş ülkelerin çoğunun STEM eğitim yaklaşımını eğitim sistemlerine entegre ettikleri görülmektedir. STEM kelimesi 2001 yılında Amerika Ulusal Bilim Vakfı yöneticisi Ramaley tarafından öne sürülmüştür (NRC, 2011). Özellikle Amerika Birleşik Devletlerinin (ABD) eski başkanı Barack Obama' nın STEM eğitimine verdiği önem şu sözlerinde açık bir şekilde görülmektedir: “... Geleceğin liderliği, öğrencilerimizi özellikle STEM alanlarında nasıl eğiteceğimize bă̆hıdır (Obama, 2010)." Bu da STEM eğitiminin geleceğin liderliğine yön vereceğine inanıldığını göstermektedir. STEM eğitimi son yıllarda birçok ülkede hızla yayılmaya başlamıştır. Çünkü gelecekte STEM eğitimi almış, yani dört farklı disiplini bir bütün içerisinde kullanmayı öğrenmiş beyinlere ihtiyacın olacağı düşünülmektedir (Çepni, 2018; TUSİAD, 2014). Bunun yanı sıra ülkeler STEM eğitimini daha çok ekonominin güçlenmesini sağlayan, bilimsel ve teknolojik olarak kalkınmalarında etkili olabilecek bir sistem olarak görmektedir (Şahin, 2013). Türkiye'deki gelişmelere bakıldığında ise Milli Eğitim Bakanlığı'nın STEM eğitimine yönelik çağrılarının (Millî Eğitim Bakanlığı [MEB], 2016) sonucu olarak bu yaklaşım, güncel Fen Bilimleri Dersi Öğretim Programı'nda beceri ve öğrenme alanına mühendislik ve tasarım becerilerinin eklenmesiyle karşımıza çıkmaktadır (MEB, 2018).

STEM eğitiminin fen derslerine entegrasyonuna, fizik dersinde yerçekimi konusunun öğrencilere öğretilmesinde bir roket tasarımı yaptırmak örnek olarak verilebilir. Böylece fizik dersinde fen becerileri, teknoloji, mühendislik ve matematik entegrasyonu gerçekleştirilmiş olur (Şahin, Ayar ve Adıgüzel, 2014; Yıldırım ve Altun, 2015). Başka bir örnek verecek olursak, "Günümüzde kullandığımız saatler olmadan zamanı nasıl ölçerdiniz?" problemine çözüm bulduracak bir tasarım yaptırılabilir. Bu tasarımın fen odağında fizik, hesaplamalarının yapılmasında matematik, tasarımın gerçekleştirilmesinde mühendislik ve teknoloji disiplinleri eşgüdümlü olarak kullanılmalıdır. Mühendislik tasarımı, STEM eğitiminin bir yoludur. STEM eğitiminde mühendislik tasarımı aslında bireylere mühendisliğin sadece bir şeyler inşa etmek olmadığının farkına vardırmak ve bunun yanı sıra matematik ve teknoloji disiplinlerinden de yararlanılarak fen bilimlerinin pratik bir etkinlik ile öğretilme sürecini kapsar (Bybee, 2011; 2013). Bir başka deyişle STEM, zil çalar çalmaz unutulacak ya da ezberleyerek edinilen bilgiler yerine, mühendislik ve teknolojinin geleneksel matematik ve fen bilimine dâhil edilerek öğrencilere daha kalıcı bilgiler kazandırılmasını sağlayan bir öğrenme ortamı sunar (Hynes ve diğerleri, 2011).

STEM eğitiminin uygulanmasına yönelik geliştirilen birçok Mühendislik Tasarım Süreci (MTS) modeli bulunmaktadır (Bybee, 2013; Gencer, Doğan, Bilen ve Can, 2019; NRC, 2012). Bunlardan biri de Hynes ve diğerlerinin (2011) geliştirdiği ve 9 adımdan oluşan MTS'dir. Bu araştırmada geliştirilen STEM etkinlik örneğinde Hynes ve diğerlerinin (2011) geliştirdiği MTS adımları takip edildiği için bu model aşağıda ayrıntılı olarak açıklanmıştır. Modelin adımları;

(1)Problemin tanıtılması. MTS' ye bir sorun, problem veya ihtiyaç durumu ile başlanmalıdır (NRC, 2012). Bu süreçte öğretmen öncelikle öğrencilere yönelik çözmeleri gereken bir problem durumu geliştirir ve sunar. Geliştirilen problem 
durumunun birçok olası çözüme açı olması oldukça önemlidir (Hynes ve diğerleri, 2011; Wendell, 2008). Bu aşamada öğrencilere problemi kendi sözcükleriyle tanımlama firsatı (Koehler, Faraclas, Sanchez, Latif ve Kazarounian, 2005; Lemons, Carberry, Swan, Rogers ve Jarvin, 2010) verilerek öğrencilerin, fen bilimleri konularını öğrenirken mühendis gibi düşünerek farklı disiplinleri bir arada kullanması ve tasarım becerilerini kazanmaları sağlanır (Kolodner, 2002; Leonard, 2004). Problem durumunun kriter ve sinırlılıkları tanımlanarak (Brunsell, 2012; International Technology Education Association [ITEA], 2007; National Academy of Engineering [NAE], 2010; NRC, 2012) öğrencilere çözüm önerilerini geliştirirken göz önünde bulundurmaları istenen özelliklerin neler olduğu fark ettirilir. Ayrıca öğrencilerin probleme yönelik geliştirdikleri çözüm önerisininde test edilebilir olması gerekmektedir (NAE ve NRC, 2009).

(2) İhtiyaçların belirlenmesi. Öğrencilerin problemi fark ettikten sonra o probleme yönelik neleri bildikleri veya neleri bilmeleri gerektiğini tespit ettikleri adımdır. Bu adımda problem durumuna yönelik çözüm önerilerini geliştirmede onlara yardımcı olabilecek bilgiler edinmeleri için araştırma-sorgulama yapmaları gerekmektedir. Bu süreçte fen eğitiminin amaçlarından birisi olan araştırma-sorgulama süreci (MEB, 2018) ve STEM eğitim yaklaşımının temelini oluşturan MTS'nin birlikte kullanılması önemlidir (Karsl1-Baydere, Hacıŏlu ve Kocaman, 2019). Aynı zamanda öğrencilerin problemin çözümüne yönelik birden fazla duruma dikkat etmeleri gerektiğini keşfetmeleri beklenir. Araştırma-sorgulama sürecinin, öğrencilere problemin çözümüne giden yolun ayrılmaz bir parçası olduğu fark ettirilir (Hynes ve diğerleri, 2011).

(3) Çözüm önerilerinin geliştirilmesi. Bu adımda öğrenciler ihtiyaç duydukları gerekli bilgileri edindikten sonra problem durumunda sunulan kriter ve sinırlıliklar (Mullins, Atman ve Shuman, 1999; Radcliffe ve Lee, 1989) bağlamında probleme yönelik çözüm önerileri geliştirirler (Brunsell, 2012; Silk ve Schunn, 2008). Bu nedenle öğrencilerden birden fazla fikir oluşturmaları (Hynes ve diğerleri, 2011) ve bunları çizerek ya da yazıya dökerek kaydetmeleri istenir. Bu adımda öğrenciler grup çalışmasına teşvik edilerek, beyin fırtınası yaptırılır (Hynes ve diğerleri, 2011). Bu sırada çözüm önerileri geliştirilirken öğrencilerin bireysel yaratıc1lıkları, grup çalışması sürecinde birbirleriyle fikirlerini paylaşırken ise iletişim becerileri ön plana çıkar.

(4) En iyi çözümün seçilmesi. MTS'nin bu adımı bir problem durumuna yönelik o problemin kriter ve sinırlılıklarına hizmet eden ve birden çok çözüm yolu içerisinden bireysel veya grup ile mümkün olan en iyi çözümün belirlenip tasarımının gerçekleştirildiği aşamasıdır (NRC, 2012). Probleme yönelik bireysel olarak sunulan çözüm kişi için en iyisi görülebilir fakat bu çözüm yolu bir başkası için en iyi çözüm olarak nitelendirilmeyebilir (Hynes ve diğerleri, 2011). Bu aşamada öğrenciler bir mühendis gibi düşünür, çözüm önerilerini kriter ve sınırlllıklara hizmet edebilirlik düzeyinde değerlendirir (Brunsell, 2012; Mentzer, 2011; NRC, 2012). Bununla birlikte çözümlerinin olumlu ve olumsuz yanlarını karşılaştırarak kimi zaman bazı kriter ve sinırlılıkları es geçerek (Brunsell, 2012; ITEA, 2007; NAE ve NRC, 2009; NRC, 2012; Silk ve Schunn, 2008; Karsl1-Baydere ve diğerleri 2019) en iyi çözüm önerisini belirlerler.

(5) Prototipin yapılması. Prototip, gerçekleştirilmesi mümkün olan bir çözümün temsili bir modeli (Maki ve Thompson, 2006) niteliğindedir. Bu adımda öğrencilerden, problem durumundaki kriter ve sinırllıklara hizmet eden ve gerçekleştirilmesi mümkün olan en iyi çözüm yoluna karar vermeleri istenir. Bu adımdan sonra 
öğrencilerin bir tasarım oluşturmalarına izin verilir (Carberry, Swan, Lemons, Jarvin ve Rogers, 2009). Öğrencilerin tasarımlarına ulaşana kadar yinelemeler yapmaları önemlidir (Koehler ve diğerleri, 2005). Tasarım her zaman başarılı bir şekilde işe yaramak zorunda değildir. Hatta tasarımların başarısız olması; öğrencilerin yaptıkları araştırmalar sonrasında hatalarından ders çıkarmalarını, çözümlerindeki eksiklikleri gidermelerini ve bu süreçte de öğrenmelerini sağlamış olabilir (Hynes ve diğerleri, 2011).

(6) Çözümün test edilmesi ve değerlendirilmesi. Öğrencilerin tasarımlarının başarılı olup olmadığını test ettikleri adımdır. Tasarımın problem durumundaki kriter ve sinırlılıklara uygun olup olmadığının ölçülmesi ve değerlendirilmesi gereklidir (Hynes ve diğerleri, 2011). Ayrıca bu aşamada öğrencilerin çözümlerini nasıl test edeceklerini ve tasarımın problemi ne kadar iyi karşıladığını belirlerken yaptıkları araştırma-sorgulama sürecinde yani ihtiyaçların belirlenmesi aşamasında gözden kaçırdıkları noktalar olduğunu fark etmeleri sağlanabilir (Gentili, McCauley, Christianson, Davis, Trevisan, Calkins ve Cook, 1999).

(7) Çözümün sunulması. Mühendislik aslında bir nevi sunum ve pazarlama amacıyla geliştirilen fikirleri başkalarıyla paylaşmaktır (Hynes ve diğerleri, 2011). Bu adımda da öğrenciler, sınıf arkadaşlarına ve öğretmenlerine sözlü olarak anlaşılır bir dilde ve tarzda tasarımlarının tanıtımını gerçekleştirirler (Dym, Agogino, Eris, Frey ve Leifer, 2005). Bu tanıtım öğrencilerin tasarımlarına ilişkin doğru ve eksiksiz bir şekilde düzenlenen bilgileri içermelidir (Hynes ve diğerleri, 2011). MTS' de öğrenciler sürekli iş birliği (NRC, 2012) ve birbirleri ile iletişim halinde oldukları bir süreç içerisindedir (Karsl1-Baydere ve diğerleri, 2019; Mentzer, 2011). Mühendislerin yaptıkları gibi öğrencilerin de probleme bulunan çözümü paylaşmaları onların iletişim becerilerinin gelişmesinde oldukça önemli bir süreçtir (Karsl1-Baydere, 2020).

(8) Yeniden tasarlama. Bu adımda ise öğrenciler eğer tasarımları başarılı olduysa bunun nasıl gerçekleştiğinin veya tam tersi başarısız olduysa neden başarısız olduğunun cevabını ararlar (Hynes ve diğerleri, 2011). Bu adımda öğrenciler tasarımlarını revize etmeye yönlendirilmektedir (Koehler ve diğerleri, 2005). Aynı zamanda bu adım, problem durumundaki kriter ve sınırlılıkları gidermeye yönelik bir ürünün geliştirilmesi ve son halini almasına kadar geçen sürede yapılan tüm çalışmaları kapsar.

(9) Tasarımın tamamlanması. Bu adımda öğrenciler gerekli revizyonları yaptıktan sonra, tasarımlarının problem durumundaki gereksinimleri tam olarak karşıladıkları bir ürünün uygulanmaya hazır olduğuna karar verirler (Gentili ve diğerleri, 1999). Aynı zamanda öğrenciler, tüm bu MTS basamaklarından elde ettikleri deneyimleri günlük yaşamda karşılaştıkları farklı durumlara entegre edebilirler.

STEM eğitimini konu alan literatürdeki çalışmalar incelendiğinde MTS'ye göre geliştirilen ve uygulaması yapılan birçok etkinliğin olduğu görülmektedir (Strimel, Bartholomew, Purzer, Zhang ve Ruesch, 2020; Aydın ve Karsl1-Baydere, 2019; Eroğlu ve Bektaş, 2016; Gökbayrak ve Karışan, 2017; Karslı Baydere ve diğerleri, 2019; KarslıBaydere ve Kurtoğlu, 2019; Tarkın-Çelikkıran ve Aydın-Günbatar, 2017; Yıldırım, 2017; Yıldırım ve Altun, 2015). Bununla birlikte literatürdeki STEM eğitim yaklaşımına yönelik birçok araştırmada ortaöğretime odaklanılmıştır (Örneğin; Aydın-Günbatar, 2018; Kang ve Keinonen, 2017; Masnick, Valenti, Cox ve Osman, 2010; Sáinz ve Müller, 2018). Ancak daha küçük yaştaki öğrencilere öğretim yapan öğretmenlere ve yapacak olan öğretmen adaylarına yönelik STEM eğitmine yönelik çalışmaların sayılarının 
artması bu yaklaşımın yaygınlaştırılması, kullanılması ve mühendislik mesleğine yönelimin arttırılması açılarından son derece önemlidir. Hacıoğlu, Şahin-Çakır, KarslıBaydere ve Yamak, (2020) yaptıkları çalışmalarında STEM uygulamalarını bir kez deneyimlemiş öğretmen adaylarının bu yaklaşımla ilgili olumlu görüşlere sahip oldukları ancak ileri de öğrencilere uygulatma konusunda endişelerinin olduğu sonucuna ulaşmışlardır. Bu nedenle STEM eğitimine yönelik etkinliklerin okul öncesi, ilkokul ve ortaokulda doğru uygulanması için öncelikle eğitim fakültelerinde öğrenim gören öğretmen adaylarının bu yaklaşımı tanıması ve deneyimlemesine yönelik daha fazla sayıda çalışmaların yapılması gerektiği düşünülmektedir. Ayrıca öğretmen adaylarının bu yaklaşım doğrultusunda gerçekleştireceği uygulamalar ile STEM'e yönelik tutum ve motivasyonlarının artışı sağlanabilir. Bu durumda öğretmen adayları, ileri ki yıllarda öğretmen olduklarında kendi öğrencilerine STEM etkinlikleri uygulama noktasında daha istekli olabilirler. Literatür incelemelerinden öğretmen adaylarına yönelik STEM eğitim yaklaşımında birçok fen konusunun ele alındığı görülmektedir (Aydın-Günbatar, Tarkın-Çelikkıran Kutucu ve Ekiz-Kıran, 2018; Bozkurt Altan, Yamak ve Buluş Kırıkkaya, 2016; Çetin ve Balta, 2017; Hacıoğlu, 2017; Kınık Topalsan, 2018;Özçakır-Sümen ve Çalışıc1, 2016; Radloff ve Güzey, 2016; Üçüncüoğlu ve BozkurtAltan, 2018). Örneğin Aydın-Günbatar ve diğerleri (2018) öğretmen adaylarına kimyasal reaksiyonlar ve enerji, asit ve bazlar, kimyasal denge ve elektrokimya konularına yönelik tasarım temelli STEM eğitimi uygulamaları yaptırmışlardır. Çetin ve Balta (2017) ise enerji ve basınç konuları kapsamında STEM eğitimi uygulamaları yaptırarak öğretmen adaylarının görüşlerini almışlardır. Özçakır-Sümen ve Çalışıcı (2016) çevre konusu kapsamında STEM uygulamalarına yer vermiştir. Üçüncüoğlu ve Bozkurt-Altan'ın (2018) öğretmen adaylarına sağlıklı yaşam konusuna yönelik STEM eğitimine yönelik etkinlikler geliştirdikleri görülmektedir. Ancak günlük yaşamımızın problemlerinden olan ve hepimizi yakından ilgilendiren "bakteriler ve diş sağlı̆̆ı" konusunun öğretiminde diş çürüklerini önleyici bir tasarımın geliştirilmesine yönelik yapılmış bir çalışmaya rastlanılmamıştır. Bu kapsamda çalışmanın, literatüre katkı sağlayıcı nitelikte olduğu söylenebilir.

\section{Araştırmanın Amacı}

$\mathrm{Bu}$ araştırmada amaç, STEM eğitimi yaklaşımına göre MTS adımları dikkate alınarak geliştirilen ve fen bilgisi öğretmen adaylarına uygulanan "diş çürüklerini önleyici" isimli STEM etkinliği hakkında öğretmen adaylarının etkinliğe yönelik görüşlerini incelemektir.

\section{Yöntem}

Araştırmada nitel araştırma yöntemlerinden biri olan özel durum çalışması (case study) yöntemi kullanılmıştır. Özel durum çalışması eğitim araştırmalarında yaygın şekilde kullanılan, araştırmacıya araştırılan durum hakkında derinlemesine inceleme ve bilgi edinme noktasında imkân sunan nitel bir araştırma yöntemidir (Çepni, 2012; Merriam, 1998; Y1ldırım ve Şimşek, 2011).

\section{Çalışma Grubu}

Araştırılan durumun ayrıntılı bir şekilde incelenmesinin amaçlandığı araştırmalarda çalışma grubunu oluşturan kişilerin sayısı az olmalıdır (Büyüköztürk, Kılıç-Çakmak, Akgün, Karadeniz ve Demirel, 2018; Özmen ve Karamustafaoğlu, 2019). Bu doğrultuda 
yürütülen araştırmanın çalışma grubunu, 2019-2020 eğitim öğretim yılında Doğu Karadeniz bölgesinde bulunan bir devlet üniversitesinde eğitim fakültesi 3. sinıfta öğrenim gören ve Fen Laboratuvarı Uygulamaları I dersini alan 7 (4 kız, 3 erkek) fen bilgisi öğretmen adayı oluşturmaktadır.

Öğretmen adayları biri üç ve diğeri dört kişiden oluşan iki gruba ayrılmışlardır. Birbirleriyle uyumlu bir şekilde çalışabileceği öngörülen öğretmen adayları aynı gruba dâhil edilmiştir. Çalışma grubunda yer alan öğretmen adayları daha önceden bir STEM eğitim uygulamasına katılmamışlardır. Bununla birlikte öğretmen adayları bakteriler ve diş sağlığı konularını birinci sınıfta genel biyoloji dersinde protozoalarla ilgili olarak basit düzeyde deneyler yaparak deneyim edinmişlerdir. Sonuç olarak öğretmen adayları 3. sınıfa gelinceye kadarki süreçte bakteri kültürü oluşturma ve diş çürüklerine neden olan bakterilerin azalmasını sağlayıcı bir tasarım yapmamışlardır.

\section{Veri Toplama Araçları}

Araştırmanın verileri, diş çürüklerine sebep olan bakteriler konusuna yönelik geliştirilen etkinlik hakkında hazırlanmış yarı yapılandırılmış görüşme soruları ile toplanmiştır.

Yarı yapılandırılmış görüşme soruları, bir çalışmada araştırmacıya, cevap aradığı sorularla ilgili bireylerden ayrıntılı bilgi almasını sağlayan nitel bir veri toplama aracıdır (Büyüköztürk ve diğerleri, 2018). Görüşme soruları, geliştirilen STEM etkinliği ve uygulama süreci ile ilgili fen bilgisi öğretmen adaylarının görüşlerinin alınması amacıyla literatürde var olan çalışmalarda kullanılan sorular inceledikten sonra araştırmacılar tarafından hazırlanmıştır. Görüşme sorularının geçerliğinin sağlanması amacıyla fen eğitimi alanında uzman olan üç araştırmacının görüşüne başvurulmuştur. Örneğin, uzmanlardan birisi başlangıçta "Yapılan etkinliğin size katkı sağladığını düşünüyor musunuz? Hangi açılardan katkı sağladığını düşünüyorsunuz? (Öğrenme, motivasyon, araştırma vb.) Başka hangi açılardan katkısının olduğunu düşünüyorsunuz? Düşünmüyorsanız, nedenlerini açıklayınız." şekline hazırlanan mülakat sorusuna "öğrenmeye etkisinden bahsedilmesi durumunda sorulabilir" şeklindeki eleştirisi ve düzeltme önerisine göre bu soru "Yapılan etkinliğin size katkı sağladığını düşünüyor musunuz? Eğer düşünüyorsanız hangi açılardan katkı sağladığını düşünüyorsunuz? Düşünmüyorsanız, nedenlerini açılayınız." şeklinde revize edilmiştir. Yarı yapılandırılmış görüşme soruları, uzmanlardan alınan geri dönütlerin incelenmesi ve gerekli görülen kısımların yeniden düzenlenmesi ile son hâlini almıştır. Etik olarak kimlik gizliliğinin sağlanması için öğretmen adayları A1, A2, ... A7 kodları ile tanımlanmıştır. Görüşmeler, öğretmen adaylarının izni dâhilinde ses kayıt cihazı kullanarak kayıt altına alınmış bu sayede veri kaybının önüne geçilmiştir. Kayıt altına alınan sesler tekrar tekrar dinlenerek öğretmen adaylarının ifadeleri elektronik ortamda her kelime olduğu gibi doğrudan yazıya dökülmüş ve bu yazılar öğretmen adaylarına okutularak söyledikleri hakkında kendilerinden teyit alınmıştır. Uzman görüşlerinin alınması ve öğretmen adaylarının görüşlerinden doğrudan alıntılar yapılarak iç geçerlik sağlanmıştır. Ayrıca iki araştırmacı birbirinden bağımsız olarak kodlamaları yapmış ve fikir birliğine varılan ortak kodlar kullanılmıştır. Kodlayıcılar arasındaki uyum yüzdesine bakıldığında \%80 oranında uyuşmanın olduğu belirlenmiştir. Bulunan bu değerin güvenilir olduğu söylenebilir (Miles ve Huberman, 1994). Araştırmada kullanılan yarı yapılandırılmış görüşme soruları aşağıda sunulmuştur. 
Soru 1: Yaptığınız etkinlikte ilginizi çeken bölüm veya bölümler nelerdi? Nedenleriyle açıklayınız.

Soru 2: (i) Diş çürüklerini önlemek amactyla geliştirdiğiniz ürün tasarm süresince size uygulanan etkinlikler hakkında ne düşünüyorsunuz?

(ii) Yapılan etkinliğin size katkı să̆ladı̆̆ını düşünüyor musunuz? Ĕ̆ger düşünüyorsanız hangi açılardan katkı sağladığıı düşünüyorsunuz? Düşünmüyorsanız, nedenlerini açıklayınız.

Soru 3: Yapılan etkinlikte en çok (i) sevdiğiniz (ii) zorlandığınız kısım veya kısımlar hangileriydi? Nedenlerini açıklayınız.

Soru 4: Fen bilimleri laboratuvar uygulamalar dersinde STEM etkinlikleri ile yapılan uygulamaların sizce (i) avantajları (ii) dezavantajları nelerdir? Açılayını.

Soru 5: Etkinlik süresince grup çalışması yaparken neler hissettiniz?

Soru 6: Fen Bilimleri dersinin bundan sonra bu tür etkinlikler ile işlenmesini ister misiniz? Nedenlerini açıklayınız.

\section{STEM Etkinliğinin Geliştirilmesi}

STEM eğitimini konu alan çalışmalar incelendiğinde "bakteriler ve diş sağlı̆̆ı" konusunun öğretiminde diş çürüklerini önleyici tasarımın geliştirilmesine yönelik bir araştırmaya rastlanılmamıştır. STEM etkinlik örneği, çalışmanın giriş bölümünde ayrıntılı olarak açıklanan ve toplamda 9 adımdan oluşan Hynes ve diğerleri (2011) tarafından geliştirilen MTS modeli örnek alınarak geliştirilmiştir. Bu bölümde geliştirilen STEM etkinlik örneğinin MTS basamakları ayrıntılı bir şekilde sunulmuştur.

I-Problemin tanımlanması. MTS'nin ilk adımı olan bu bölümde öğretmen adaylarına günlük yaşamda karşılaşabilecekleri bir problem durumu ve bu duruma çözüm aramak isteyebilecekleri düşünülen bir problem senaryosu oluşturulmuştur. Buradaki amaç, öğretmen adaylarının “Neden bunu yapmalıyım? / Neden bu ürünü tasarlamalıyım ki?” sorularına karşı gerekçe sunabilmektir. Araştırmacılar dikkat çekici bir problem senaryosu oluşturmak amaciyla güncel yaşamdaki gerçek verilerden yararlanmışlardır. Kriter ve sınırlılıklar problem senaryosuna gömülü halde öğretmen adaylarına sunularak öğretmen adayların bu iki kavramı fark etmeleri sağlanmaya çalışılmıştır. Aşağıda Şekil 1'de problem senaryosu sunulmuştur. 


\section{"ÇÜRÜK ÖNLEYİCI"}

Sağlık Bakanlığının araştırmalarına göre Türkiye'de diş ve diş eti hastalıklarmm yaygın olarak gözlendiği ve yetişkin her 100 kişiden 90'ında çürük diş, 85'inde ise diş eti hastalığı mevcut olduğu tespit edilmiştir. Ayrıca diş çürüğü görülme sıklığı 6 yaş grubu çocuklarda yüzde $88^{\prime}$ dir. Bu konuda yapılan araştırma verilerine göre diş ve diş eti hastalıklarına sebep olan ağız içerisinde bulunan mikroorganizmalardır.

Bireylerin çok fazla şekerli besinler tüketmeleri ve ağız bakımlarına dikkat etmemeleri bu mikroorganizmaların ağız ve diş sağlığın tehdit etmelerine sebebiyet vermektedir. Özellikle küçük yaşlardan itibaren dişlerin düzenli bir șekilde furçalanması gelecekte ki diş kayıplarını önlemenin en büyük şartıdır. Günümüzde diş fırçalama davranışı özellikle evebeynlerin çocuklarına kazandırmakta oldukça zorlandıkları bir konudur. Çocukların gerek diş macununun tadını beğenmemeleri gerekse diş fırçasından kaynaklı sebeplerden bu davranışları kazanamadıkları görülmektedir. İște tam bu yüzden Sağlık Bakanlığının siz değerli gençlerden "22-27 Kasım Toplum Ağız ve Diş Sağlığı" Haftasına özel bir isteği var. Çocukların diş sağlıklarını koruma davranışını kazanmalarında etkili olabileceği düşünülen ve antibakteriyel özelliği sayesinde diş çürüklerini önleyici, diș yüzeyine bakterilerin tutunmasını engelleyici yapısı olan, yapımında tamamen doğal ürünlerin kullanıldığı, insan sağlığını tehdit etmeyecek nitelikte ve çocukların ağzında acı bir tat birakmayacak özgün bir ürün tasarlamanız... Tasarladığınız ürünün ekonomik olması oldukça önemli olup toplam ürün maliyeti en fazla 30 TL olmalıdır. Unutmayın sevgili gençler bu tasarım sayesinde binlerce çocuğun ağız ve diș sağlığını korumasına yardımcı olabilirsiniz. Tüm ilgililere duyurulur.

Şekil 1. Öğretmen adaylarına sunulan problem senaryosu

Problem senaryosu okunduktan sonra araştırmacılar öğretmen adaylarına, "Sevgili gençler sizce okumuş olduğunuz duyurudaki problem durumu nedir?" ve "Problem durumunda sunulan kriter ve sinırlılklar nelerdir? Yazını." şeklinde yönergeler sunmuşlardır.

II- İhtiyaçların belirlenmesi. Bu basamakta problemi fark eden öğretmen adaylarına sonuca ulaşmalarında yardımcı olacak bilgileri araştırmaları için " $\mathrm{Bu}$ problemi çözmek için neler biliyorum ve bunlara ek olarak neleri bilmem gerekiyor" yönergeleri sunulmuştur. Araştırmacılar tarafından problem durumunun çözümünde öğretmen adaylarına araştırma-sorgulama sürecinde ve tasarımlarını gerçekleştirmelerinde onlara yardımcı olabileceği düşünülen "A ğ̆ı içerisinde yayılış gösteren bakteriler nelerdir? Araştırınız." sorusuna benzer yönlendirici sorular yöneltilmiştir.

III- Çözüm önerilerinin geliştirilmesi. Bu basamakta ise araştırma sorgulama sürecini tamamlayan öğretmen adaylarından problemin çözümüne yönelik bireysel olarak hayal ettikleri ve gerçekleştirmek istedikleri birden fazla çözüm önerisi geliştirmeleri istenmiştir. Çözüm önerilerini yazan/çizen öğretmen adaylarına yazdıkları çözüm önerilerini gerçekleştirmede neleri bilmeleri gerektiği ile ilgili boş bir alan bırakılmıştır. Bunun amacı çözümlerini gerçekleştirirken neleri bilmeleri gerektiğinin farkında olmalarını sağlamaktır.

IV- En iyi çözümün seçilmesi. Öğretmen adaylarından bu aşamada problem durumunu en iyi hizmet eden çözüm yolunu seçmeleri ve diğer grup arkadaşlarına gerekçelendirerek çözüm önerisini sunmaları istenmiştir (Bkz Şekil 2). Bu aşamada seçilen çözüm önerisinin, problem senaryosuna gömülü halde bulunan kriter ve 
sınırlılıklar bağlamında diğer gruplar ve öğretmen eşliğinde değerlendirilmesi beklenir.

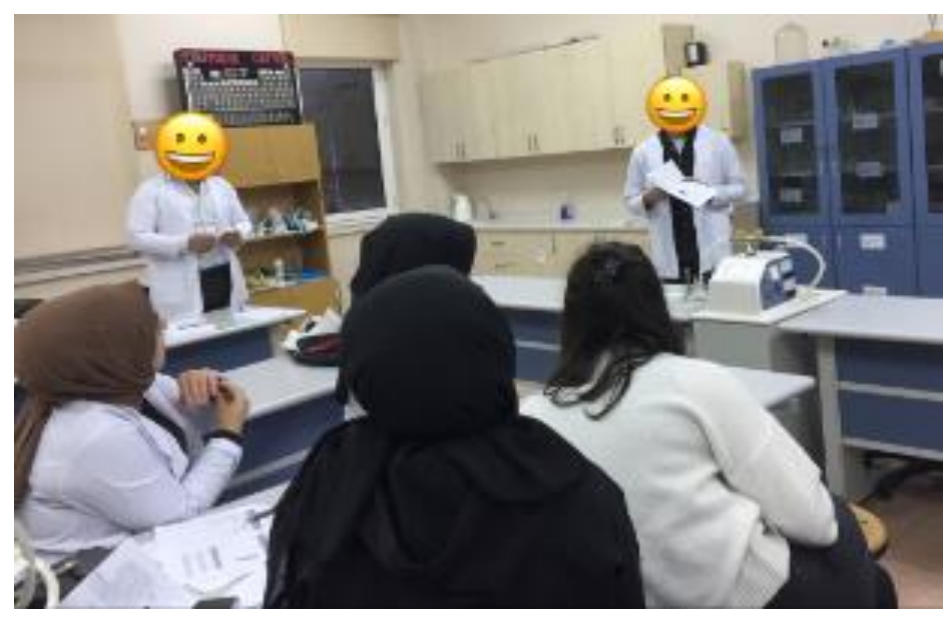

Şekil 2. Öğretmen adayları çözüm önerilerini sunarken

Daha sonra öğretmen adaylarından kendilerine verilen problem durumuna çözüm olabilecek tasarımlarını yapmak için ihtiyaç duyacakları malzemeleri listelemeleri (kendilerine verilen bütçeye dikkat ederek) istenmiştir.

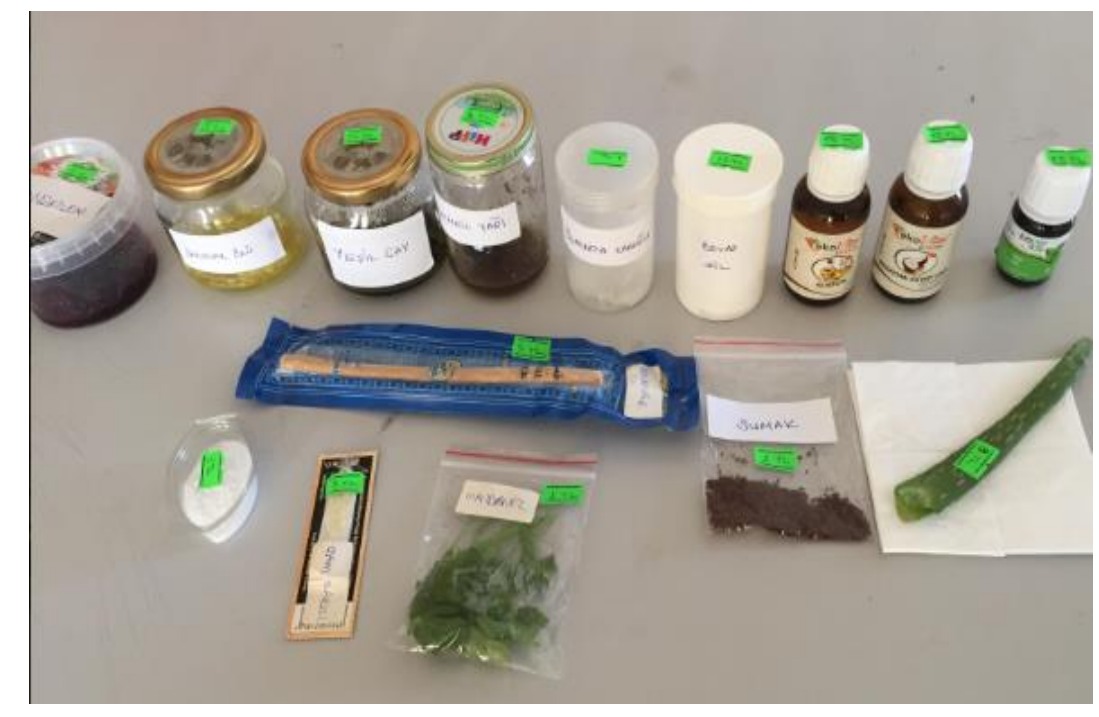

Şekil 3. Öğretmen adaylarının tasarımları için belirlediği malzemeler

V- Prototipin yapılması. Bu aşamada öğretmen adaylarına "Sevgili gençler, bu aşamada aldığınız geri dönütler ışı̆̆ında, grup arkadaşlarınıla birlikte öğretmeninizin size temin ettiği malzemeleri kullanarak ürünün tasarımını gerçekleştirebilirsiniz." yönergesi verilmiştir. Öğretmen adaylarının belirlediği malzemeler araştırmacılar tarafından temin edilerek gruplara verilmiş (Bkz Şekil 3) ve onlar tasarımlarını yapmaya başlamışlardır (Bkz Şekil 4). 


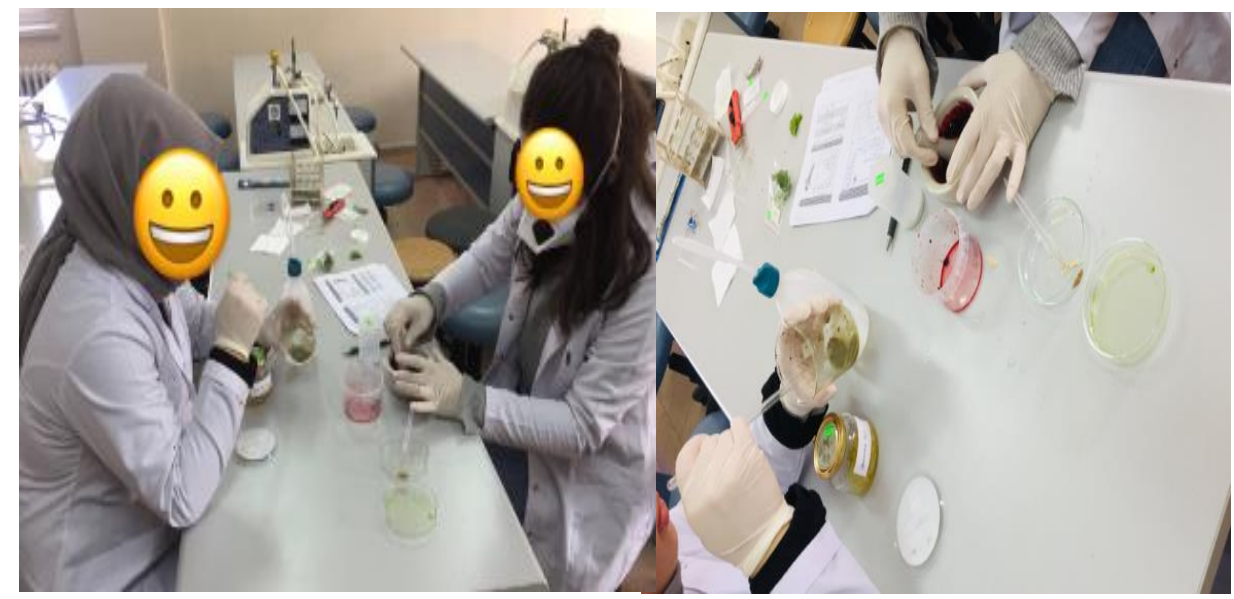

Şekil 4. Öğretmen adayları tasarımlarını yaparken

VI- Çözümün test edilmesi ve değerlendirilmesi. Tasarımlarını gerçekleştiren öğretmen adaylarına "Geliştirmiş olduğunuz ürününüzü test ederek değerlendiriniz." ve "Tasarımın gerçekleştirmiş olduğunuz ürününüzün problemi çözüme kavuşturup kavuşturmadı̆̆ıı test etmek amacıyla kriter ve sınırlılıklar bağlamında değerlendiriniz. Bunun için size verilen değerlendirme rubriğini kullanınız." şeklinde yönergeler sunulmuştur. Öğretmen adayları Şekil 5'te verilen değerlendirme rubriğine göre tasarımlarını değerlendirmişlerdir.

\begin{tabular}{|c|c|c|}
\hline \multirow{2}{*}{$\begin{array}{l}\text { Özellikler } \\
\text { Geliştirmiş olduğunuz ürün diş çürüklerine neden } \\
\text { olan bakterilerin sayısını azaltmada etkili oldu } \\
\text { mu? }\end{array}$} & Evet (5 puan) & Hayır(0 puan) \\
\hline & & \\
\hline $\begin{array}{l}\text { Ürün yapımında tamamen doğal ürünler mi } \\
\text { kullanıldı? }\end{array}$ & & \\
\hline $\begin{array}{l}\text { Insan sağlığına zarar verecek maddeler içeriyor } \\
\text { mu? }\end{array}$ & & \\
\hline $\begin{array}{l}\text { Tasarladığınız ürünün toplam maliyeti } 30 \text { TL'yi aştı } \\
\text { mı? }\end{array}$ & & \\
\hline
\end{tabular}

Şekil 5. Tasarımların değerlendirilmesi için kullanılan rubrik

VII- Çözümün sunulması. Bu aşamada öğretmen adaylarına "Sevgili gençler tasarımını gerçekleştirmiş olduğunuz ürününüzün özelliklerini sınıf arkadaşlarınıza ve öğretmeninize sununuz. Ürününüz probleme çözüm sundu mu? Diğer grup arkadaşlarınıdan ve ögretmeninizden tasarımınıla ilgili aldığınız dönütleri not alını.." şeklinde yönerge sunulmuştur.

VIII- Yeniden tasarlama. Öğretmen adayları bu basamakta tasarımlarını sunduktan sonra almış oldukları dönütler ile birlikte tasarımlarında herhangi bir eksiklik olup olmadığını grup arkadaşlarıyla tartışarak tasarımlarını yeniden geliştirirler. Bunun için öğretmen adaylarına "Arkadaşlarınızın size vermiş olduğu dönütler ışığında ürününüzün eksik kaldığı veya yeniden tasarlamak istediğiniz kısımları tespit ederek ürününüzü geliştiriniz." yönergesi sunulmuştur. 
IX- Tasarımın tamamlanması. MTS'nin son basamağı tasarımın tamamlanmasıdır. Bu basamakta öğretmen adaylarının MTS basamaklarını takip ederek geliştirdikleri STEM etkinlik örneğinden edindikleri deneyimlerini güncel yaşama veya farklı durumlara aktarabilmeleri sağlanmaya çalışılır. Bu yüzden araştırmacılar adaylara iki farklı seçenek sunmuşlardır (Bkz Şekil 6). Bu seçeneklerden biri broşür hazırlama görevi bir diğeri ise kamu spotu oluşturma görevidir. Öğretmen adaylarından bu basamağın amacına uygun olarak bu iki seçenekten birini belirleyerek görevi yerine getirmeleri istenir.

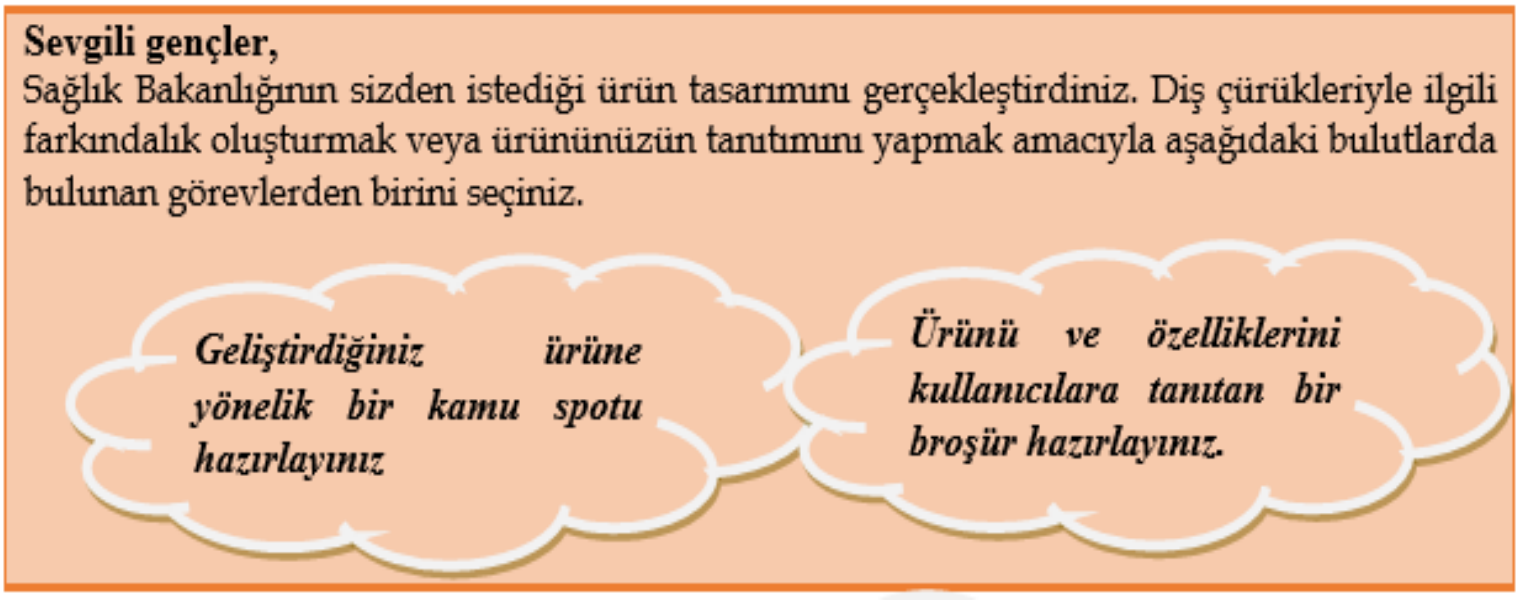

Şekil 6. Öğretmen adaylarına sunulan broşür ya da kamu spotu oluşturma görevi

\section{Etkinliğin Uygulanma Süreci}

Araştırmacılar tarafından geliştirilen STEM etkinliği öğretmen adaylarına uygulanmadan önce tüm adımların ayrıntılı olarak yazıldığı bir ders planı ve yukarıda da bahsedildiği gibi bir etkinlik kağıdı oluşturulmuştur. Günlük yaşamımızda geliştirilen tasarımlara ve ürünlere baktığımızda feni matematik, teknoloji ve mühendislik disiplinlerinin birlikte kullanıldığını görmekteyiz. Bu nedenle öğretim kurumlarında laboratuvar uygulamalarında günlük yaşam problemlerine çözüm buldurmaya yönelik fen, mühendislik, teknoloji ve matematik disiplinlerin harmanlanması gerektiği vurgulanmaktadır (Harkema, Jadrich ve Bruxvoort, 2009). Bununla birlikte laboratuvar etkinliklerinde eş zamanlı olarak MTS' nin kullanılmasının öğrencilerin derse ilgisini daha fazla çekeceğini ve daha kalıcı öğrenmeler sağlayabileceğini de belirtilmektedir. Harkema ve diğerleri (2009)'nin de önerisi kapsamında uygulamalar araştırmacılar tarafından bir fen laboratuvarında yapılmıştır. Yapılan etkinliğin grup çalışması şeklinde yürütülmesinin öğrencilerin iletişim becerilerinin geliştirilmesi açısından ve iş birliği yapma konusunda olumlu bir etki yaratacağ1 bilinmektedir (Bybee, 2010; Bozkurt, 2014; Erdoğan, Çorlu ve Capraro, 2013; Kolodner, Crismond, Gray, Holbrook ve Puntambekar, 1998). Bu sebeple araştırmacılar öğretmen adaylarını, üç ve dört kişiden oluşan iki gruba ayırmışlar ve öğretmen adaylarından gruplarına bir isim bulmalarını istemişlerdir. Daha sonra öğretmen adaylarına STEM eğitimine dair fikirleri olup olmadığını belirlemek amacıyla sorular yönlendirilmiştir. Uygulamanın amacı, konusu ve süreç ile ilgili öğretmen adayları bilgilendirilmiş olup akabinde her öğretmen adayına bir etkinlik kağıdı dağıtılarak her adayın sürece etkin katılımı sağlanmaya çalışılmıştır. 
Araştırmacılar, problem senaryosunu öğretmen adaylarının okumasını isteyerek problemi fark etmelerini hedeflemişlerdir. Öğretmen adaylarının probleme yönelik bilgileri edinmek için teknolojiyi kullanarak (akıllı telefonlar, bilgisayar vs.) araştırma yapmaları sağlanmıştır. Öğretmen adayları bir mühendis gibi düşünerek çözüm önerileri geliştirmeye teşvik edilmiştir. Daha sonra etkinlik kâğıdındaki MTS basamaklarını tek tek takip ederek geliştirmek istedikleri ürünün tasarımını gerçekleştirmişlerdir. Öğretmen adayları tasarımlarında kullandıkları malzemelerin miktarını ve fiyatını belirlemede matematiksel işlemlerden yararlanarak STEM eğitiminin bir diğer disiplinini de etkinliklerinde kullanmışlardır. Disiplinler arası bir çalışmayı gerektiren bu süreçte öğretmen adaylarının tasarımlarını test etmelerini sağlamak için üniversitenin biyoloji bölümünde görev yapan bir öğretim üyesinin yardımına başvurulmuştur. Araştırmacılar uygulama öncesinde diş çürüklerine sebep olan bakterileri, literatür incelemeleri sonunda tespit etmişlerdir. Problem durumundaki kriter ve sınırlılıklar açısından maliyeti en aza indirmek için üremesi en kolay ve üniversitenin laboratuvarında mevcut olan bir bakteri türünü tercih etmeleri yönünde öğretmen adaylarının araştırma yapmaları sağlanmıştır. Öğretmen adaylarınca tamamlanan tasarımlar besi yerine ekilmiş ve etüvde bekletilen bakteri suşları üzerine enjekte edilerek tasarımların problemin çözümüne cevap verip vermedikleri test edilmiştir. Test sonuçlarına göre kendilerine 3G1M ismi veren grubun yapmış olduğu 'Çamsa' isimli tasarımın ağızda yayılış gösteren ve diş çürüklerine sebep olan bakterinin azalmasında etkili olduğu, Kizçeler grubunun 'Solüsyon' isimli tasarımının ise ağı içerisinde yayılış gösteren ve diş çürüklerine sebep olan bakterinin üzerinde bir etkisinin olmadığı görülmüştür. Yapılan test etme işleminden sonra öğretmen adaylarına tasarımlarının sonuçlarını değerlendirmeleri açısından kriter ve sınırlılıkları içeren bir rubrik sunulmuştur. Bu rubriğe göre tasarımlar değerlendirilmiştir. Haftanın pazartesi ve çarşamba günlerinde uygulanmış olan bu STEM etkinliğinin uygulanması toplam 4 hafta $(8 \times 50$ dakika) sürmüştür. Etkinlik uygulamasının ardından her bir öğretmen adayı ile etkinlikle ilgili yarı yapılandırılmış görüşmeler yapılmıştır.

\section{Verilerin Analizi}

Araştırma kapsamında kullanılan yarı yapılandırılmış görüşme sorularının analizinde içerik analizi yöntemi kullanılmıştır. İçerik analizi, nitel araştırma verilerinin incelenmesinde kodlama yapma, temaların oluşturulması, kod ve temaların düzeltilmesi ve araştırmanın bulgularının yorumlanması noktasında kullanılır (Yıldırım ve Şimşek, 2011). Analizde öğretmen adaylarının sorulara verdikleri cevapları karşılayan, kodlar ve kodları en iyi kapsayan temalar oluşturulmuştur. Örneğin araştırmada öğretmen adaylarının "Yaptığınız etkinlikte ilginizi çeken bölüm veya bölümler nelerdi? Nedenleriyle açıklayınız." sorusuna verdikleri cevaplar transkript edildikten sonra etkinlikte ilgi çeken bölümler teması altında "Ürünün tasarlanması", "Çözümün test edilmesi", "Araştırma-sorgulama aşaması" ve "En iyi çözüm yolunun seçilmesi" kodlar1 oluşturulmuştur.

\section{Bulgular}

STEM eğitimi yaklaşımına göre geliştirilen ve fen bilgisi öğretmen adaylarına uygulanan "diş çürüklerini önleyici" isimli STEM etkinliği hakkında öğretmen adaylarının görüşlerini incelemek amacıyla yürütülen bu araştırmada öğretmen 
adaylarına uygulanan yarı yapılandırılmış mülakatlardan elde edilen bulgular Tablo 1 'de sunulmuştur.

Tablo 1.

Öğretmen Adaylarının Yarı Yapılandırılmış Görüşme Sorularnna Verdikleri Cevaplardan Elde Edilen Bulgular

\begin{tabular}{|c|c|c|c|}
\hline Tema & Kod & f & Alıntı İfade \\
\hline \multirow{4}{*}{ 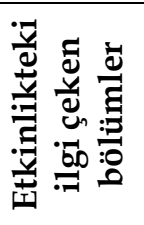 } & Ürünün tasarlanması & 3 & "Bir ürün oluşturmaya çalışmak benim ilgimi çekmişti."(A2) \\
\hline & Çözümün test edilmesi & 3 & "...benim için sonucun test edilmesi çok önemliydi."(A7) \\
\hline & Araştırma-sorgulama & 2 & "Araştırma-sorgulama bölümü."(A1) \\
\hline & $\begin{array}{l}\text { En iyi çözüm yolunun } \\
\text { seçilmesi }\end{array}$ & 2 & $\begin{array}{l}\text { "... herkesin farklı bir düšüncesini alıp en iyisini bulmaya gidilen } \\
\text { kısım çok hoşuma gitmişti."(A7) }\end{array}$ \\
\hline \multirow{3}{*}{ 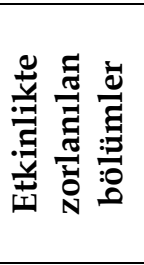 } & Araştırma-sorgulama & 4 & $\begin{array}{l}\text { "...hangi maddeler katılırsa daha faydalı olur diye araştırırken } \\
\text { zorlandım."(A7) }\end{array}$ \\
\hline & Ürünün tasarlanması & 3 & $\begin{array}{l}\text { "Tasarladık ya hani o süreç biraz zorlayıcıydı nasıl bir şey } \\
\text { yapacağımız açısından..."(A5) }\end{array}$ \\
\hline & $\begin{array}{l}\text { Matematiksel } \\
\text { yapma }\end{array}$ & 1 & $\begin{array}{l}\text { "...belli bir fiyat arahı̆ımız vardı bunları tek tek hesaplayıp } \\
\text { yapmakta zorlandım." (A2) }\end{array}$ \\
\hline \multirow{8}{*}{ 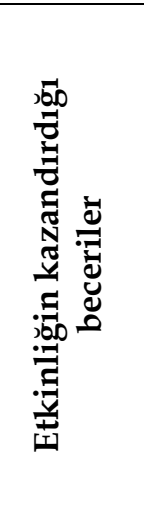 } & Araştırma & 7 & "Öğrencinin bir şeyi araştırmasını sağlıyor bence."(A7) \\
\hline & Problem çözme & 4 & $\begin{array}{l}\text { "...öğrenci o probleme nasıl bir çözüm önerisi sunacağını } \\
\text { araştırmayı merak eder."(A1) }\end{array}$ \\
\hline & Sorgulama & 3 & “...sorgulama yapmayı ögrrendik."(A2) \\
\hline & Yorum yapma & 2 & "...yorumlamayı öğrendim."( A2) \\
\hline & Analiz yapma & 2 & $\begin{array}{l}\text { "...dışarıda karşıma bir problem gelse o probleme yönelik } \\
\text { analizler yaparım."(A1) }\end{array}$ \\
\hline & Düşünme & 1 & "Öğrenci hangi çözüm yolunu seçeceğini düşünüyor."(A1) \\
\hline & Karar verme & 1 & $\begin{array}{l}\text { "...çözüme yönelik daha güzel fikirler düşünen, karar veren, } \\
\text { daha yeni şeyler ortaya çıkarabilen öğrenciler olabilir."(A1) }\end{array}$ \\
\hline & İletişim & 1 & $\begin{array}{l}\text { "...kendini kelimelerle ifade etme süreci olarak bence olumlu bir } \\
\text { çalışmaydr."(A3) }\end{array}$ \\
\hline \multirow{14}{*}{ 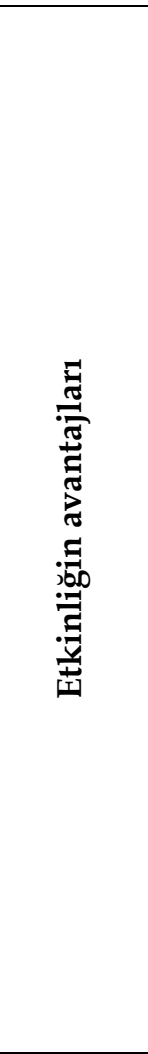 } & Aktif katılım & 12 & "Bu etkinlikte öğrenci daha çok ve sürekli aktif."(A1) \\
\hline & $\begin{array}{ll}\text { Grup } & \text { çalışmasını } \\
\text { destekleme }\end{array}$ & 10 & $\begin{array}{l}\text { "Grup çalışması olması açısından birlikte çalışmayı } \\
\text { destekliyor."(A6) }\end{array}$ \\
\hline & $\begin{array}{ll}\text { Yaparak } & \text { yaşayarak } \\
\text { öğrenme } & \end{array}$ & 9 & “...̈̈ğrenci kendi yaparak yaşayarak öğreniyor."(A7) \\
\hline & Merak uyandirma & 8 & $\begin{array}{l}\text { "...bir merak duygusu var o merak duygusu seni probleme doğru } \\
\text { itiyor."(A1) }\end{array}$ \\
\hline & $\begin{array}{l}\text { Farklı problemleri } \\
\text { çözmeye katkı }\end{array}$ & 7 & $\begin{array}{l}\text { "Bir problemle karşı karşıya gelsem bu problem aklıma gelir ben } \\
\text { bu problemde nasıl sonuca ulaştım ben ne yaptım nasl } \\
\text { araştırmalar yaptım hangi yolları izledim mesela hangi yerlerden } \\
\text { araştırma yaptım bu yollar tekrardan izlerim." (A1) }\end{array}$ \\
\hline & Eğlenceli & 7 & "Hiç sıkılmadım eğlenceli geçiyordu."(A5) \\
\hline & Dikkat çekici & 5 & “...ne çözüm önerebiliriz sorusu dikkatimizi çekti."(A2) \\
\hline & Kavramsal anlama & 5 & $\begin{array}{l}\text { "Kişi herşeyi kendisi yaptı̆̆ı için kavramları ö̆grenmek } \\
\text { kolaylaşıyor."(A7) }\end{array}$ \\
\hline & Yeni bilgiler öğrenme & 4 & “...bakteri açısından daha çok şey öğrendim."(A4) \\
\hline & Motivasyon & 3 & “... çözüm önerileri geliştirdikçe derse motive oluyorsun."(A1) \\
\hline & Farklı bakış açısı & 3 & $\begin{array}{l}\text { "Farklı düşünceler kullanıldığı için daha farklı açılardan } \\
\text { görebiliyorsun."(A2) }\end{array}$ \\
\hline & ğrenme & 3 & “...Böylece bilginin kahıcılı̆̆ı olur kendisi yaptığı için."(A7) \\
\hline & $\begin{array}{l}\text { Sorumluluğun } \\
\text { paylaşılması }\end{array}$ & 2 & “...senin sorumluluğun paylaşılmış oluyor."(A2) \\
\hline & $\begin{array}{l}\text { Özgür bir ortamda } \\
\text { çalışma imkânı }\end{array}$ & 2 & $\begin{array}{l}\text { "...aslında zorlandı̆̆ım kısım yoktu çünkü özgür bir } \\
\text { çalışmaydı."(A3) }\end{array}$ \\
\hline
\end{tabular}




$\begin{array}{lcccc}\begin{array}{l}\text { Özgün fikrini uygulama } \\ \text { imkânı }\end{array} & 2 & \text { “...burada tamamen kendi fikrimizi yaptık."(A4) } \\ \text { Kendini değerli hissetme } & & \text { “...Etkinlik hoşuma gitti hani ben kendimi değerli } \\ & 1 & \text { hissettim."(A4) }\end{array}$

\begin{tabular}{|c|c|c|c|c|}
\hline \multirow{5}{*}{ 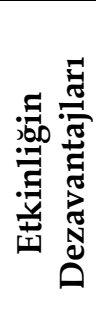 } & \multicolumn{2}{|c|}{ Kalabalık sınıf ortamı } & 6 & "Bu yaklaşım benimsenecekse kalabalik bir sinffta olmaz."(A6) \\
\hline & Maliyet & & 2 & “...ekonomik olmayabilir."(A6) \\
\hline & Süre sıkıntısı & & 2 & “...süre açısından uzun sürer."(A5) \\
\hline & Sınıf yönetimi & & 2 & $\begin{array}{l}\text { "10 kişilik } 5 \text { grup kursak bunun belki kontrolü hâkimiyeti } \\
\text { sağlamak zor olur."(A5) }\end{array}$ \\
\hline & $\begin{array}{l}\text { Öğrencilerin } \\
\text { durumu }\end{array}$ & başarı & 1 & $\begin{array}{l}\text { "Bu sinıfta çok iyi olan öğrencide olacak çok kötü olan öğrencide } \\
\text { buradaki kötü ögrrenci biraz daha pasif duruma düşebilir o } \\
\text { yüzden dezavantajı olabilir."(A7) }\end{array}$ \\
\hline
\end{tabular}

f: Frekans (İfade edilme sıklığı)

Tablo 1'deki öğretmen adaylarının görüşme sorularına verdikleri cevaplardan elde edilen bulgular incelendiğinde etkinlik ile ilgili olarak "etkinlikteki ilgi çeken bölümler", "etkinlikte zorlanılan bölümler", "etkinliğin kazandırdığ1 beceriler", "etkinliğin avantajları" ve "etkinliğin dezavantajları" olmak üzere toplam beş farklı temanın oluşturulduğu görülmektedir. Etkinlikteki ilgi çeken bölümler teması altında dört kod oluşturulmuştur. Bu kodlardan ilki olan ürünün tasarlanması kodu öğretmen adaylarının ifadelerinde üç kez rastlanmıştır. Bu koda ait örnek bir ifade "Bir ürün oluşturmaya çalışmak benim ilgimi çekmişti."(A2) şeklindedir. Yine üç kez tekrarlanan ikinci kod ise çözümün test edilmesidir. Bu koda ait örnek bir ifade“...benim için sonucun test edilmesi çok önemliydi."(A7) şeklindedir. Araştırma-sorgulama kodunda iki kez öğretmen adayları tarafından araştırma-sorgulama sürecinin ilgi çekici özellikte olduğu tekrarlanmıştır. Bu temaya ait dördüncü kod ise en iyi çözüm yolunun seçilmesidir. İki kez tekrarlanan bu koda ait örnek ifade“... herkesin farklı bir düşüncesini alıp en iyisini bulmaya gidilen kısım çok hoşuma gitmişti." (A7) şeklindedir.

Etkinlikte zorlanılan bölümler teması altında ise en sık tekrarlanan araştırma sorgulama kodudur. Bu kodu ürünün tasarlanması ve matematiksel işlem yapma kodu takip etmektedir. Öğretmen adaylarının görüşlerinden ortaya çıkan bir diğer tema ise etkinliğin kazandırdığı beceriler temasıdır. Bu tema altında sırasıyla araştırma, problem çözme, sorgulama, yorum yapma, analiz yapma, düşünme, karar verme ve iletişim becerileri kodları oluşturulmuştur. Bu tema altında yedi öğretmen adayınında tekrarladığı araştırma kodu dikkat çekmektedir. Etkinliğin avantajları teması altında aktif katılım, grup çalışmasını destekleme, yaparak yaşayarak öğrenme, merak uyandırma, farklı problemleri çözmeye katkı, eğlenceli, dikkat çekici, kavramsal anlama, yeni bilgiler öğrenme, motivasyon, farklı bakış açısı, kalıcı öğrenme, sorumluluğun paylaşılması, özgür bir ortamda çalışma imkânı, özgün fikrini uygulama imkânı ve kendini değerli hissetme kodları oluşturulmuştur. Öğretmen adayları en sık olarak aktif katılım kodunda etkinliğin avantajlı olduğuna dikkat çekmişlerdir. Bu koda ilişkin örnek bir ifade"Bu etkinlikte öğrenci daha ve sürekli aktif."(A1) şeklindedir.

Etkinliğin dezavantajı teması altında toplanan kodlar incelendiğinde 5 farklı kodun ortaya çıktığı görülmektedir. Bu kodlardan en fazla sıklıkla tekrarlanan kod kalabalık sınıf ortamıdır. Bu koda ilişkin öğretmen adaylarının ifadelerinden bir örnek "Bu yaklaşım benimsenecekse kalabalık bir sınıfta olmaz." (A6) şeklindedir. Bu kodu sirayla maliyet, süre sıkıntısı, sınıf yönetimi ve öğrencilerin başarı durumu kodları takip etmektedir. 


\section{Tartışma, Sonuç ve Öneriler}

STEM eğitimi yaklaşımına göre geliştirilen ve fen bilgisi öğretmen adaylarına uygulanan "diş çürüklerini önleyici" isimli STEM etkinliği hakkında öğretmen adaylarının görüşlerini incelemek amacıyla yapılan bu araştırma kapsamında öğretmen adaylarının etkinlikle ilgili olarak kavramsal anlama, kalıcı öğrenme ve yaparak yaşayarak öğrenme gibi kodlara sıklıkla vurgu yaptıkları görülmüştür. Bu durum etkinliğin kendilerinde kavramsal anlamayı desteklediği şeklinde yorumlanabilir. Benzer şekilde literatürdeki birçok araştırma bu sonucu destekler niteliktedir (Brown, Brown, Reardon ve Merrill, 2011; Cantrell, Pekcan, Itani ve Velasquez-Bryant, 2006; Claymier, 2014; Doppelt, Mehalik, Schunn, Silk ve Krysinski, 2008; Gallant, 2011; Gerlach, 2010; Havice, 2009; Honey, Pearson ve Schweingruber, 2014; Katehi, Pearson ve Feder, 2009; NRC, 2010; Rogers ve Portsmore, 2004; Sanders, 2009). Nitekim STEM eğitim yaklaşımında MTS basamaklarının uygulanması öğretmen adaylarının etkinliğin her aşamasında aktif olmasını ve bütün görevleri iş birliği içerisinde tamamlayarak sonuçlandırmasını gerekli kılmaktadır. Bu durum öğretmen adaylarınında ifade ettiği gibi yaparak yaşayarak uygulanan öğrenme aktivitelerinin öğrencilerde anlamlı öğrenmeyi desteklediğine bir delil olabilir. Bununla birlikte bu bulgu Harkema ve diğerlerinin (2009) laboratuvar etkinliklerinde eş zamanlı olarak MTS'nin öğrencilerin derse ilgisini daha fazla çekeceği ve daha kalıcı öğrenmeler sağlayabileceği görüşünü de desteklemektedir.

Öğretmen adayları etkinliğin uygulanması sürecinde ürünün tasarlanması, çözümün test edilmesi, araştırma-sorgulama ve en iyi çözüm yolunun seçilmesi bölümlerinin ilgilerini çektiği yönünde açıklamalar yapmışlardır. Öğretmen adayları en çok ürünün tasarlanması bölümünü ilgi çekici bulduklarını ifade etmişler ve uygulama sürecnde kendi çözüm önerilerine yönelik tasarım yapacaklarını öğrendiklerinde oldukça heyecanlı oldukları gözlemlenmiştir. Bu durum öğretmen adaylarının ürettikleri fikirlerin sadece kâğıt üzerinde kalacağını düşünmelerinden kaynaklanmış olabilir. Bir başka neden ise öğretmen adayları STEM eğitim uygulamalarına daha önceden katılmadıkları için bu etkinlik onlar için farklı ve dikkat çekici gelmiş olabilir. Ayrıca öğretmen adaylarının ilgilerini çeken bir diğer yüksek frekansa sahip etkinlik bölümü ise yaptıkları tasarımların test edilme aşamasıdır. Öğretmen adaylarının etkinliğin farklı farklı aşamalarında ilgilerinin çekilmesi sağlanarak dersin daha eğlenceli bir hale getirilmesi buna bağlı olarak motivasyonlarının yükseltilmesi sağlanmaya çalışılmıştır (Küçük ve Şişman, 2017; Sungur, Gül ve Marulcu, 2014). Öğretmen adaylarının etkinliğin uygulama adımlarından onları zorlayan bölümlere verdikleri cevaplar ise araştırma sorgulama, matematiksel işlem yapma ve ürünün tasarlanması aşamalarıdır. Bu araştırmada öğretmen adaylarının yanıtlarından elde edilen bulgular, konunun çözümüne ulaşmada kendilerine yardımcı olan bilgileri araştırma aşamasında zoruluklarla karşılaştıklarını göstermektedir. Elde ettiğimiz bu sonuca paralel olarak Karsl1-Baydere ve diğerleri (2019) yapmış oldukları araştırmalarında araştırma-sorgulama bölümünde öğretmen adaylarının zorluklar yaşadıklarını belirtmişlerdir. Karsl1-Baydere (2020) yapmış olduğu araştırmada da lisansüstü öğrencilerinin STEM etkinlik geliştirme sürecinde literatür tararken zorluklar yaşadıklarını tespit etmiştir. Aynı zamanda öğrencilerin matematiksel işlemleri kullanılarak gram ve maliyet hesapları yaparken (Cebesoy ve Yeniterzi, 2016; Çorlu ve Aydın, 2016) ve öğretmen adaylarının ürün tasarlarken (Bozkurt-Altan, Yamak ve Buluş-Kırıkkaya, 2016) çeşitli zorlular 
yaşadıkları bilinmektedir. Sonuç olarak etkinliğin ilgi çeken ve zorlanılan bölümlerinin olmasının, öğretmen adaylarının süreç boyunca aktif olmalarını sağlaması ve onların ders sürecinde dikkatlerini sürekli canlı tutmalarını sağlaması şeklinde yorumlanmaktadır.

"Diş çürüklerini önleyici" isimli etkinliğin öğretmen adaylarına, araştırma, problem çözme, analiz yapma, düşünme, karar verme, yorum yapma, sorgulama ve iletişim becerilerinin kazandırılmasında etkili olduğu tespit edilmiştir. Bu durum STEM eğitimine yönelik etkinliklerin öğrencilerin bazı 21. yy becerilerinin gelişimine katkı sağladığı şeklinde yorumlanabilir. Bu araştırmada da öğretmen adayları tarafından en sik tekrarlanan araştırma yapma becerisi ve problem çözme becerisi kodudur. Bu durum STEM eğitimine yönelik etkinliklerin öğretmen adaylarının araştırma yapma becerilerini geliştirdiği ve araştırma yaparak bilgiye ulaşmayı destekleme konusunda bireylere imkân tanıdığı sonuçlarını destekler niteliktedir. Problem çözme becerisinin kazandırılması aynı zamanda araştırma becerisini de beraberinde getirmektedir. Böylece uygulanan etkinlik ile kazandırılan 21. yy becerileri sayesinde öğretmen adaylarının edindikleri becerileri günlük yaşamlarında karşılaştıkları problemlerin çözümünde kullanmaları sağlanmış olabilir (Öner ve Özdem-Yılmaz, 2019). Sonuç olarak etkinliğin öğretmen adaylarının bazı 21. yy becerilerini kazanmasında etkili olduğu sonucuna ulaşılabilir. Nitekim literatürdeki bazı çalışmalarda bu sonucu destekler niteliktedir (Çakır, Ozan, Kaya ve Buyruk, 2016; Ercan ve Bozkurt, 2013; Mentzer, 2008; Şahin ve diğerleri, 2014).

Uygulanan STEM etkinliğinin öğretmen adaylarına kazandırdığı avantajlar ise aktif katılım, grup çalı̧̧masını destekleme, yaparak yaşayarak öğrenme, merak uyandırma, farklı problemleri çözmeye katkı, eğlenceli, dikkat çekici, kavramsal anlama, yeni bilgiler öğrenme, motivasyon, farklı bakış açısı, kalıcı öğrenme, sorumluluğun paylaşılması, özgür bir ortamda çalışma imkanı, özgün fikrini uygulama imkanı ve kendini değerli hissetmedir (Bkz Tablo 1). Tablo 1 incelendiğinde en sık tekrarlanan avantajın aktif katılım olduğu görülmektedir. Öğretmen adaylarının hepsi etkinliğin, derse aktif katılımlarını sağlamada etkili olduğu yönünde görüş bildirmişlerdir. Bu bulgu STEM etkinliğinin, öğretmen adaylarını süreç boyunca bir mühendis gibi düşündürerek, problemlerin çözümüne yönlendirmesine, tasarım aşamalarında kısaca sürecin tamamında aktif hale getirdiği söylenebilir. Bu durum süreç boyunca öğretmen adaylarının aktif bir şekilde ve yaparak yaşayarak sürece dâhil olmasının sonucu olarak öğrenmelerin kalıcı olmasını desteklemektedir (Yıldırım, 2017). Nitekim öğrenme sürecinde aktif katılım, yaparak yaşayarak öğrenme ve sonucunda da anlamlı öğrenmelerin ve kavramsal anlamaların oluşması beklenen bir durumdur (NRC, 2010; Özçakır Sümen ve Çalışıcı, 2016; Karslı-Baydere, Ayas ve Çalık, 2020). Öğretmen adayları STEM etkinliği sayesinde yeni bilgiler edindiklerini de belirtmişlerdir. Bu durum STEM eğitim yaklaşımında bireylerin bilmeye ihtiyaç duydukları bir aşama yardımıyla araştırmaya yönlendirilmelerinin bir sonucu olarak düşünülmektedir (Tarkın-Çelikkıran ve Aydın-Günbatar, 2017). Buna ek olarak öğretmen adayları etkinliğin grup çalışmasını desteklediğini sıklıkla tekrarlamışlardır. Bu durum da STEM etkinliklerinin iş birliği içerisinde herkesi ilgilendiren bir problem üzerinde çözüm odaklı bir yaklaşımla çalışmalarına katkı sağladığı şeklinde yorumlanabilir. Nitekim STEM etkinliklerinin grup çalışmalarını desteklediği yönündeki sonuçlar bu durumu desteklemektedir (Aydın ve Karslı-Baydere, 2019; Karsl1-Baydere ve Kurtoğlu, 2019). STEM etkinliklerinin öğretmen adayları açısından 
diğer avantajları arasında merak uyandırma yer almaktadır. Merak duygusu bireyi öğrenmeye ve bilmeye istekli olmayı sağlar. Dolayısıyla bu isteklilik ilgilenilen konuya öğretmen adaylarının motive olmasını ve dikkatini vermesini sağlamış olabilir (Aydın ve Karslı Baydere, 2019; Eroğlu ve Bektaş, 2016; Küçük ve Şişman, 2017). Ayrıca öğretmen adaylarının ifadelerinden STEM etkinliğinin kendilerine farklı bir bakış açısı kazandırdığı sonucuna da ulaşılmıştır. Bu durum adaylara sunulan günlük yaşam problemine çözüm sürecinde birçok çözüm önerisi sunmalarının beklenmesinin ve gerek kendi grup arkadaşlarının gerekse diğer gruplardan farklı fikirleri dinlemeye özen gösterilmesinin bir sonucu olabilir. Bu sonuç STEM etkinliklerinin problemin çözümüne ulaşırken farklı düşünmeyi ve yaratıcılığı ön plana çıkarmayı desteklediğini göstermektedir (Hanif, Wijaya ve Winarno, 2019). Öğretmen adaylarının ifadelerinden STEM etkinliğinin sorumlulukları paylaşmayı desteklediği anlaşılmaktadır. Bu durum STEM etkinliklerinin grup çalışması eşliğinde yapılmasının birer yansıması olabilir. Nitekim grup çalışmalarının yardımlaşma ve paylaşma duygularını geliştirdiği, sorumluluk bilincinin oluşmasına yardımcı olduğu ve sorumluluk bilincinin artmasına katkı sağladığı bilinmektedir (Yasul ve Samancı, 2015). Ayrıca grup çalışmaları yapılırken öğretmen adaylarına tamamen özgür bir ortamda çalışma imkânı sunulmuştur. Bu durum öğretmen adaylarına özgür bir ortamda, özgün fikirlerini uygulama imkânı sunulmuş olmasının bir sonucu olarak kendilerini daha değerli hissetmelerine sebep olmuş olabilir. Nitekim bireylere özgür birer çalışma ortamları sunulduğunda her bir grup üyesinin paylaşılmış görevi başarmaktan sorumlu hale geldiği ve başarma duygusuna sahip kişilerin ise kendilerini değerli hissettikleri bilinmektedir (Johnson ve Johnson, 2008). Araştırmadan elde edilen diğer önemli bir sonuç ise gerçekleştirilen STEM etkinliğinin öğretmen adaylarının farklı problemleri çözmelerine katkı sağlamasıdır. MTS basamaklarının son adımı olan tasarımın tamamlanması aşamasında bireylere kazandırılması istenen davranış, öğrendikleri problem çözme basamaklarını günlük yaşamdaki diğer problemlerin çözümünde kullanabilmeleridir. Bu araştırmada da "diş çürüklerini önleyici” isimli STEM etkinliği ile öğretmen adaylarının MTS basamaklarını keşfetmeleri sağlanmış ve günlük yaşamda okul içi veya okul dışında karşılaştıkları farklı problemlerin çözümünde öğrendikleri MTS basamaklarını kullanmaları sağlanmış olabilir (Gökbayrak ve Karışan, 2017; Tarkın-Çelikkıran ve Aydın-Günbatar, 2017). Araştırmada öğretmen adaylarına özgün fikirlerini uygulama imkânı verilmiştir. Bu durumun da kendilerini değerli hissetme ve özelliklerinin farkına varmaları konusunda öğretmen adaylarına katkı sağladığı ve öğretmen adaylarının özgüvenlerini artırdığ1 söylenebilir (KarslıBaydere, 2020).

STEM etkinliğinin kullanıldığı bu araştırmada öğretmen adaylarının etkinlik ile ilgili dezavantaj olarak gördükleri bazı konular tespit edilmiştir. Bunlar; kalabalık sınıf ortamı, maliyet, süre sıkıntısı, sınıf yönetimi ve öğrencilerin başarı durumu gibi sorunlardır. Nitekim en sık tekrarlanmış olan kalabalık sınıflara STEM eğitiminin uygulanmasında karşılaşılabilecek sorunlardır. Bu sonuç araştırmacıların uygulama sürecindeki gözlemlerinden yola çıkılarak; uygulamanın uzun zaman alması, uygulayıcının sınıf kontrolü ve bireylerin özgün fikirlerini ortaya çıkarmada malzeme özgürlüğüne sahip olma noktasında zorlanabileceklerini düşündükleri şeklinde yorumlanabilir. Morrison (2006) bir STEM sınıfında gerekli koşulların; bilgisayar donanımı, farklı özellikteki materyal çeşitliliği ve her öğrenciye uygun ortam olduğunu belirtmektedir. Özellikle eğitim için düşük bütçenin ayrıldığı okullarımızda bu 
ortamların kalabalık sınıflarda sağlanması güçleşmektedir. Öğretmen adayları bu nedenlerle kalabalık sınıflarda uygulamaların zor olacağına dikkat çekmiş olabilirler. Buradan STEM etkinliklerinin uygulanmasinda sinif mevcuduna dikkat edilmesi gerektiği sonucuna ulaşılabilir. Öğretmen adaylarının belirttikleri bu dezavantajlar dikkate alınmalı ve eğitim sistemimize entegre edilen MTS süreci bu dezavantajlara göre düzenlenmelidir. Böylece uygulamada yaşanılacak sorunların giderilmesi mümkün olabilir. STEM etkinliği ile ilgili diğer dezavantajlar olan maliyet, süre sıkıntısı ve sınıf yönetimi gibi zorluklar literatürdeki diğer çalışmaların sonuçlarında da sıklıkla tekrarlanan dezavantajlardandır (Eroğlu ve Bektaş, 2016; Siew, Amir ve Chong, 2015).

Özetle, "bakteriler ve diş sağlığı" konusuna yönelik geliştirilen etkinliğin öğretmen adaylarının kavramsal anlamalarını artırdığı ve bazı 21. yy becerilerinin gelişmesine katkı sağladığı sonucuna ulaşılmıştır. Ayrıca etkinliğin öğretmen adayları açısından bazı dezavantajları olmasına rağmen, kendilerine çoğunlukla olumlu özellikler kazandırdığı, eğlenceli bir ortam sunarak derse karşı motivasyonlarını artırdığı ve öğrencilerin sürece aktif katılımına imkân sunarak, yaparak yaşayarak bir öğrenme sürecinde bulunmalarına olanak sağladığı sonuçlarına ulaşılmıştır.

$\mathrm{Bu}$ araştırma sonuçlarından elde edilen veriler ve uygulama sürecindeki araştırmacı deneyimleri ışı̆̆ında STEM etkinliklerine yönelik yapılacak olan çalışmalar için öneriler:

- Bu çalışmada öğretmen adaylarının sıkça günlük yaşamda karşılaştıkları bir problem durumu ele alınmaya çalışılmıştır. Fakat çözümün test edilmesi aşaması için gerekli olan ağı florasındaki mikroorganizmaların temin edilmesi ve öğretmen adayları tarafından geliştirdikleri ürünün test etmeleri aşamalarında araştırmacılar oldukça zorlanmıştır. Buradan yola çıkılarak mikroorganizmlar ile çalışacak araştırmacıların laboratuar imkanlarını göz önünde bulundurmaları önerilir.

- Yine çalışma kapsamında geliştirilen etkinlik kâğıdının öğrencilerin sürece aktif katılımlarında destekleyici bir rol oynadığı gözlemlenmiştir. Bu konuda çalışma yapacak araştırmacıların öğretim sürecini bireysel etkinlik kâğıtları ile sürdürmeleri önerilmektedir.

- $\mathrm{Bu}$ araştırmada geliştirilen ve uygulanan STEM etkinliğinde matematik boyutu ürün tasarımı sırasında oran orantı işlemleri ve maliyet hesabıyla sınırlı kalmıştır. $\mathrm{Bu}$ noktada bu etkinliği uygulayacak olan öğretmen ya da gelecek araştırmacılara besi yerlerinin sayımı için model oluşturularak etkinliği matematik entegrasyonu hususunda daha da zenginleştirmeleri önerilmektedir.

- Özellikle geleceğin öğretmenleri olacak olan öğretmen adaylarının STEM eğitim yaklaşımına yönelik etkinlikleri daha fazla deneyimlemesi sağlanmalı bunun için eğitim fakültelerinde STEM eğitim yaklaşımı dersi seçmeli ders olarak okutulabilir.

\section{Teşekkürr}

Araştırmaya MTS'nin test etme sürecinde, öğretmen adaylarının geliştirdiği tasarımların besi yerine ekilmesi ve etüvde bekletilen bakteri suşları üzerine enjekte edilerek sonuçlarının gözlenmesi süreçlerindeki katkılarından dolayı Giresun Üniversitesi öğretim üyelerinden Doç Dr. Tamer AKKAN’a teşekkür ederiz. 


\section{Kaynakça}

Akgündüz, D., Aydeniz, M., Çakmakçı, G., Çavaş, B., Çorlu, M., Öner, T., ve Özdemir, S. (2015). STEM eğitimi Türkiye raporu: “Günümüz modası mı yoksa gereksinim mi?". İstanbul: İstanbul Aydın Üniversitesi STEM Merkezi.

Aydın, E., ve Karslı-Baydere, F. (2019). Yedinci sınıf öğrencilerinin STEM etkinlikleri hakkındaki görüşleri: Karışımların ayrıştırılması örneği. Ondokuz Mayıs Üniversitesi Eğitim Fakültesi Dergisi, 38(1), 35-52

Aydın-Günbatar, S. (2018). Elmanın kararmasının engellenmesi: Bir FeTeMM Etkinliği. Araştırma Temelli Etkinlik Dergisi, 8(2), 99-110.

https:// doi.org/10.14527/9786052415382.01

Aydın-Günbatar, S., Tarkın-Çelikkıran, A., Kutucu, E. S. and Ekiz-Kıran, B. (2018). The influence of a design-based elective STEM course on pre-service chemistry teachers' content knowledge, STEM conceptions, and engineering views. Chemistry Education Research and Practice, 19, 954-972. https:/ / doi.org/10.1039/C8RP00128F

Bozkurt, E. (2014). Mühendislik tasarım temelli fen eğitiminin fen bilgisi öğretmen adaylarnın karar verme becerisi, bilimsel süreç becerileri ve sürece yönelik algılarma etkisi (Yayınlanmamış doktora tezi) Gazi Üniversitesi, Eğitim Bilimleri Enstitüsü, Ankara.

Bozkurt-Altan, E., Yamak, H. ve Buluş-Kırıkkaya, E. (2016). FETEMM eğitim yaklaşımının öğretmen eğitiminde uygulanmasına yönelik bir öneri: Tasarım temelli fen eğitimi. Trakya Üniversitesi Ĕ̆itim Fakültesi Dergisi, 6(2), 212-232

Brophy, S., Klein, S., Portsmore, M., and Rogers, C. (2008). Advancing engineering education in p-12 classrooms. Journal of Engineering Education, 97(3), 369-387. https:/ / doi.org/10.1002/j.2168-9830.2008.tb00985.x

Brown, R., Brown, J., Reardon, K., and Merrill, C. (2011). Understanding STEM: Current perceptions. Technology and Engineering Teacher, 70(6), 5-9.

Brunsell, E. (2012). The engineering design process. In Brunsell, E. (Ed.), Integrating Engineering + Science in Your Classroom (pp. 3-5). Arlington, Virginia: National Science Teacher Association [NSTA].

Büyüköztürk, Ş., Kılıç-Çakmak, E., Akgün, Ö.E., Karadeniz, Ş., ve Demirel, F. (2018). Bilimsel araștırma yöntemleri. Ankara: PegemYayınları. https:/ / doi.org/10.14527/9789944919289

Bybee, R. W. (2010). Advancing STEM education: A 2020 Vision. Technology and Engineering Teacher, 70(1), 30-35.

Bybee, R. W. (2011). Scientific and engineering practices in K-12 classrooms: understanding "a framework for k-12 science education. Science and Children, 49(4), 10-16.

Bybee, R. W. (2013). The case for STEM education: Challenges and opportunities. NSTA press.

Çakır, R., Ozan, C. E., Kaya, E., and Buyruk, B. (2016). The impact of FeTeMM activities on 7th grade students' reflective thinking skills for problem solving levels and their achievements. Participatory Educational Research (PER), 4, 182189.

Cantrell, P., Pekcan, G., Itani, A., and Velasquez-Bryant, N. (2006). The effects of engineering modules of student learning in middle school science classrooms. 
Journal of Engineering Education, 95(4), 301-309.

https:// doi.org/10.1002/j.2168-9830.2006.tb00905.x

Carberry, A., Swan, C., Lemons, G., Jarvin, L., and Rogers, C. (2009). Investigating engineering design through model-building. In Research in Engineering Education Symposium, Queensland, Australia.

Cavanagh, S., and Trotter, A. (2008). Where's the ' $\mathrm{T}$ ' in STEM? Technology counts, STEM: The push to improve sciecne, technology, engineering and maths. Education week, 27th March.

http:/ / www.edweek.org/ew/articles/2008/03/27 /30stemtech.h27 .html sayfasından erişilmiştir.

Cebesoy, Ü. B., and Yeniterzi, B. (2016). 7th grade students' mathematical difficulties in force and motion unit. Turkish Journal of Education, 5(1), 18-32.

Çepni, S. (2012). Araştırma ve proje çalışmalarına giriş̧ (Geliştirilmiş 6. Baskı). Trabzon: Celepler Matbaacilık.

Çepni, S. (2018). Kuramdan uygulamaya STEM eğitimi. Pegem Atıf İndeksi, 001-633. https://doi.org/10.14527/9786052410561

Çetin, A. and Balta, N. (2017). Pre-Service Science Teachers Views on Stem Materials and Stem Competition in Instructional Technologies and Material

Development Course. European Journal of Educational Research, 6(3), 279-288. https:// doi.org/10.12973/eu-jer.6.3.279

Claymier, B. (2014). Integrating STEM into the elementary curriculum. Children's Technology and Engineering, 18(3), 5.

Çorlu, M. A., and Aydin, E. (2016). Evaluation of learning gains through integrated STEM projects. International Journal of Education in Mathematics, Science and Technology, 4(1), 20-29. https://doi.org/10.18404/ijemst.35021

Doppelt, Y., Mehalik, M. M., Schunn, C. D., Silk, E., and Krysinski, D. (2008). Engagement and achievements: A case study of design-based learning in a science context. Journal of Technology Education, 19(2), 22-39.

Dym, C. L., Agogino, A. M., Eris, O., Frey, D. D., and Leifer, L. J. (2005). Engineering design thinking, teaching, and learning. Journal of Engineering Education, 94(1), 104-120. https://doi.org/10.1002/j.2168-9830.2005.tb00832.x

English, L. D., and King, D. T. (2015). STEM learning through engineering design: fourth-grade students' investigations in aerospace. International Journal of STEM Education, 2(1), 1-18. https:/ / doi.org/10.1186/s40594-015-0027-7

Ercan, S., and Bozkurt, E. (2013). Expectations from engineering applications in science education: Decision-making skill. InIOSTE Eurasian Regional Symposium and Brojerage event Horizon 2020, Antalya, Turkey.

Erdogan, N., Corlu, M. S., and Capraro, R. M. (2013). Defining innovation literacy: do robotics programs help students develop innovation literacy skills? International Online Journal of Educational Sciences, 5(1), 1-9.

Eroğlu, S., ve Bektaş, O. (2016). STEM eğitimi almış fen bilimleri öğretmenlerinin STEM temelli ders etkinlikleri hakkındaki görüşleri. Egütimde Nitel Arasstırmalar Dergisi,4(3), 43-67. DOI: 10.14689/issn.2148-2624.1.4c3s3m.

Gallant, D. (2011). Science, technology, engineering, and mathematics (STEM) education. https://www.mheonline.com/mhmymath/pdf/stem_education.pdf adresinden 16 Mart 2016 tarihinde edinilmiştir. 
Gencer, A. S., Doğan, H., Bilen, K. ve Can, B. (2019). Bütünleşik STEM eğitimi modelleri. Pamukkale Üniversitesi Eğitim Fakültesi Dergisi, 45(45), 38-55. https:/ / doi.org/10.9779/PUJE.2018.221

Gentili, K. L., McCauley, J. F., Christianson, R. K., Davis, D. C., Trevisan, M. S., Calkins, D. E., and Cook, M. D. (1999). Assessing students design capabilities in an introductory design class. In FIE'99 Frontiers in Education. 29th Annual Frontiers in Education Conference. https:/ / doi.org/10.1109/FIE.1999.840348

Gerlach, J. W. (2010). Elementary design challenges: fifth-grade students emulate Nasa aerospace engineers as they design and build styrofoam and paper clip planes. Science $\mathcal{E}$ Children, 47(7), 43-47.

Gökbayrak, S. ve Karışan, D. (2017, Ekim). Fen bilgisi öğretmen adaylarının STEM temelli etkinlikler hakkındaki yansıtıcı yazımlarının incelenmesi. Sözlü bildiri,

2. Uluslararası Eğitimde iyi uygulamalar ve yenilikler konferansı, İzmir, Türkiye.

Hacıoğlu, Y. (2017). Fen, Teknoloji, Mühendislik ve Matematik (STEM) eğitimi temelli etkinliklerin fen bilgisi öğretmen adaylarının eleştirel düşünme becerilerine etkisi (Yayımlanmamış Doktora Tezi). Gazi Üniversitesi, Ankara.

Hacıoglu, Y., Şahin-Çakır, Ç., Karslı-Baydere, F. ve Yamak, H. (2020). The views of prospective teachers on the science spot preparation process. Turkish Journal of Teacher Education, 9(1), 64-87.

Hanif, S., Wijaya, A. F. C., and Winarno, N. (2019). Enhancing students' creativity through stem project-based learning. Journal of Science Learning, 2(2), 50-57. https:/ / doi.org/10.17509/jsl.v2i2.13271

Harkema, J., Jadrich, J., and Bruxvoort, C. (2009). Science and engineering: Two models of laboratory investigation. The Science Teacher, 76(9), 27-31

Havice W. (2009). The power and promise of a STEM education: Thriving in a complex technological world. In ITEEA (Eds.), The Overlooked STEM Imperatives: Technologyand Engineering (pp. 10-17). Reston, VA: ITEA.

Honey, M., Pearson, G., and Schweingruber, H. (Eds) (2014). STEM integration in K-12 education: status, prospects, and an agenda for research. National Academy of Engineering and National Research Council. Washington DC: National AcademiesPress.

Hynes, M., Portsmore, M., Dare, E., Milto, E., Rogers, C., Hammer, D., and Carberry, A. (2011). Infusing engineering design into high school stem courses. 8 Ağustos 2013 tarihinde http:/ / ncete.org/flash/pdfs. Infusing \% 20 Engineering \% 20 Hynes.pdf sayfasından erişilmiştir.

International Technology Education Association (ITEA). (2007). Standards for technological literacy: Content for the study of technology. Reston, VA: Author.

Johnson, R. T., and Johnson, D. W. (2008). Active learning: Cooperation in the classroom. The annual report of educational psychology in Japan, 47, 29-30. https://doi.org/10.5926/arepj1962.47.0_29

Kang, J., and Keinonen, T. (2017). The effect of inquiry-based learning experiences on adolescents' science-related career aspiration in the Finnish context. International Journal of Science Education, 39(12), 1669-1689. https:/ / doi.org/10.1080/09500693.2017.1350790

Karsl1-Baydere, F. (2020). Fen bilimleri eğitimi anabilim dalı'nda lisansüstü eğitim yapan öğrencilerin aldıkları STEM eğitim yaklaşımı dersi sürecine ilişkin 
görüşleri. International Social Mentality and Researcher Thinkers Journal, 6(39), 2649-2662. https:/ / doi.org/10.31576/ smryj.734

Karsl1-Baydere, F. ve Kurtoğlu, S. (2019). Bir fen, teknoloji, mühendislik ve matematik (STEM) eğitimi etkinlik örneği: A ğırlık ölçümü yapalım. I. Uluslararası STEM Öğretmenler Konferansında sunulmuş bildiri, İstanbul.

https://doi.org/10.24106/kefdergi.3051

Karsl1-Baydere, F., Ayas, A. and Çalik, M. (2020). Effects of a 5Es learning model on the conceptual understanding and science process skills of pre-service science teachers: The case of gases and gas laws. Journal of the Serbian Chemical Society, 85(4), 559-573.

Karsl1-Baydere, F., Hacıoğlu, Y., and Kocaman, K. (2019). An example of the science, technology, engineering, and mathematics (STEM) education activity: Anticoagulant Drugs. Kastamonu Education Journal, 27(5), 1935. https://doi.org/10.24106/kefdergi.3051

Katehi, L., Pearson, G., and Feder, M. (Eds). (2009). Engineering in K-12 education: Understanding the status and improving the prospects. National Academy of Engineering and National Research Council. Washington, DC: National AcademiesPress.

Koehler, C., Faraclas, E., Sanchez, S., Latif, K., and Kazarounian, K. (2005). Engineering frameworks for a high school setting: guidelines for technical literacy for high school students. Washington, DC: American Society for Engineering Education.

Kolodner, J. L. (2002). Facilitating the learning of design practices: lessons learned from an inquiry into science education. Journal of Industrial Teacher Education, 39(3). Web site: http:/ / scholar.lib.vt.edu/ejournals/JITE/v39n3/ adresinden 4 Haziran 2012 tarihindeedinilmiştir.

Kolodner, J. L., Crismond, D., Gray, J., Holbrook, J., and Puntambekar, S. (1998, December). Learning by design from theory to practice. In Proceedings of the International Conference of the Learning Sciences (Vol. 98, pp. 16-22). http:/ / www.cc.gatech.edu/projects/ lbd/htmlpubs/lbdtheorytoprac.html

Küçük, S., and Şişman, B. (2017). Behavioral patterns of elementary students and teachers in one-to-one robotics instruction. Computers $\mathcal{E}$ Education, 111, 31-43. https://doi.org/10.1016/j.compedu.2017.04.002

Kuenzi, J. J., Matthews, C. M., and Mangan, B. F. (2006). Science, technology, engineering, and mathematics (STEM) education issues and legislative options. Library of Congress Washington DC Congressional research service.

Lemons, G., Carberry, A., Swan, C., Rogers, C., and Jarvin, L. (2010). The importance of problem interpretation for engineering students. In ASEE Annual Conference and Exposition, Conference Proceedings. https:/ / doi.org/10.18260/1-2--16000

Leonard, M. J. (2004). Toward epistemologically authentic engineering design activities in the science classroom. National Association for Research in Science Teaching, Vancouver, B.C.

Maki, D. P., and Thompson, M. (2006). Mathematical modeling and computer simulation. Brooks/Cole Publishing Company.

Masnick, A. M., Valenti, S. S., Cox, B. D., and Osman, C. J. (2010). A multidimensional scaling analysis of students' attitudes about science careers. International Journal of Science Education, 32(5), 653-667. https:// doi.org/10.1080/09500690902759053 
MEB, (2016). STEM eğitimi raporu. Yenilik ve Eğitim Teknolojileri Genel Müdürlüğü (YEĞİTEK): Ankara.

MEB, (2018). Fen bilimleri dersi öğretim programı (ilkokul v eortaokul 3, 4, 5, 6, 7 ve 8. sinıflar) ögretim programı. Ankara: Millî Eğitim Bakanlığ

Mentzer, N. (2011). High school engineering and technology education integration through design challenges. Journal of STEM Teacher Education, 48(2), 103-136. https:// doi.org/10.30707/JSTE48.2Mentzer

Mentzer, N. J. (2008). Academic performance as a predictor of student growth in achievement and mental motivation during an engineering design challenge in engineering and technology education (Unpublished doctoral dissertation). Utah State University, Logan, Utah.

Merriam, S.B. (1998). Qualitative research and case study applications in education. San Francico: Jossey- Bass Publications.

Miles, M. B., and Huberman, A. M. (1994). Qualitative data analysis (2nd edition). Thousand Oaks, CA: Sage.

Morrison, J. (2006). TIES STEM education monograph series, attributes of STEM education. Baltimore, MD: TIES.

Mullins, C. A., Atman, C. J., and Shuman, L. J. (1999). Freshman engineers' performance when solving design problems. IEEE Transactions on Education, 42(4), 281-287. https:/ / doi.org/10.1109/13.804533

National Academy of Engineering [NAE] and National Research Council [NRC] (2009). Engineering in $k-12$ education understanding the status and improving the prospects. (Edt.) Katehi, L., Pearson, G. \& Feder, M. Washington, DC: National Academies Press.

National Academy of Engineering [NAE]. (2010). Standards for K-12 engineering education? Washington, DC: National Academies.

National Governors Association [NGA]. (2007). Innovation America: Building a science, technology, engineering and math agenda. (Washington, DC: National Governors Association, 2007).

http://www.nga.org/files/live/ sites/NGA/files/pdf/0702INNOVATIONS TEM.PDF sayfasından erişilmiştir.

National Research Council [NRC]. (2010). Standards for k-12 engineering education? Washington, DC: The National Academies Press.

National Research Council [NRC]. (2011). Successful k-12 STEM education: İdentifying effective approaches in science, technology, engineering, and mathematics. National Academies Press.

National Research Council [NRC]. (2012). A framework for $k$-12 science education: practices, crosscutting concepts, and core ideas. Washington DC: The National Academic Press.

Obama, B. (2010). Changing the equation in STEM education. http:/ / www.whitehouse.gov/blog/2010/09/16/changing-equation STEMeducation adresinden alınmıştır. ErişimTarihi: 6 Haziran 2014

Öner, G. ve Özdem-Yılmaz, Y. (2019). Ortaokul öğrencilerinin problem çözme ve sorgulayıcı öğrenme becerileri algıları ile STEM'e yönelik alg1 ve tutumları arasındaki ilişkinin incelenmesi. Cumhuriyet International Journal of Education, 8(3), 837-861. http:// dx.doi.org/10.30703/cije.574134. 
Özçakır-Sümen, Ö., and Çalışıcı, H. (2016). Pre-service teachers' mind maps and opinions on STEM education implemented in an environmental literacy course. Educational Sciences: Theory \& Practice, 16(2), 459-476.

Özmen, H., ve Karamustafaoğlu, O. (2019). Eğitimde araştırma yöntemleri. Ankara: Pegem Akademi. https:/ / doi.org/10.14527/9786052417867

Radcliffe, D. F., and Lee, T. Y. (1989). Design methods used by undergraduate engineering students. Design Studies, 10(4), 199-209.

Radloff, J., and Güzey, S. (2016). Investigating Preservice STEM Teacher Conceptions of STEM Education. Journal of Science Education and Technology, 25(5), 759-774. https:// doi.org/10.1007/s10956-016-9633-5

Rogers C., and Portsmore M. (2004). Bringing engineering to elementary school. Journal of STEM Education, 5(3 \& 4), 17-28.

Şahin, A. (2013). Stem clubs and science fair competitions: effects on post-secondary matriculation. Journal of STEM Education, 14(1), 7-13.

Şahin, A., Ayar, M. C., and Adiguzel, T. (2014). STEM related after-school program activities and associated outcomes on student learning. Educational Sciences: Theory and Practice, 14(1), 309-322. https:// doi.org/10.12738/estp.2014.1.1876

Sáinz, M., and Müller, J. (2018). Gender and family influences on Spanish students' aspirations and values in stem fields. International Journal of Science Education, 40(2), 188-203. https:/ / doi.org/10.1080/09500693.2017.1405464

Sanders, M. (2009). STEM, STEM education, STEM mania. The Technology Teacher, 68(4),20-26.

Scott, J. W. (2009). The Politics of the Veil. Princeton University Press. https:// doi.org/10.2307/j.ctt7sgmx

Siew, N. M., Amir, N., and Chong, C. L. (2015). The perceptions of pre-service and inservice teachers regarding a project-based STEM approach to teaching science. SpringerPlus, 4(8), 1-20. https:/ / doi.org/10.1186/2193-1801-4-8

Silk, E. M., and Schunn C. D. (2008). The impact of an engineering design curriculum on science reasoning in an urban setting. Journal of Science Education and Technology, 18(3), 209-223. https:/ / doi.org/10.1007/s10956-009-9144-8

Strimel, G. J., Bartholomew, S. R., Purzer, S., Zhang, L., and Ruesch, E. Y. (2020). Informing engineering design through adaptive comparative judgment. European Journal of Engineering Education, 1-20. DOI: 10.1080/03043797.2020.1718614

Sungur-Gül, K., ve Marulcu, İ. (2014). Yöntem olarak mühendislik-dizayna ve ders materyali olarak legolara öğretmen ile öğretmen adaylarının bakış açılarının incelenmesi. Turkish Studies, 9(2), 761-786. https://doi.org/10.7827/TurkishStudies.6561

Tarkın-Çelikkıran, A. ve Aydın-Günbatar, S. (2017). Kimya öğretmen adaylarının FeTeMM uygulamaları hakkındaki görüşlerinin incelenmesi. Yüzüncü Yıl Üniversitesi Ĕ̆itim Fakültesi Dergisi, 14(1), 1624-1656. https:// doi.org/10.23891/efdyyu.2017.58

Topalsan, A. K. (2018). Sınıf öğretmenliği öğretmen adaylarının geliştirdikleri mühendislik tasarım temelli fen öğretim etkinliklerinin değerlendirilmesi. Yüzüncü Yıl Üniversitesi Eğitim Fakültesi Dergisi, 15(1), 186219. https://doi.org/10.23891/efdyyu.2018.66 
TUSİAD (2014). Ticaret: Dünyada Türkiye'nin Yeri. Mevcut Durum ve Geleceğge Yönelik Adimlar.

Üçüncüoğlu, İ., ve Bozkurt Altan, E. (2018). Fen Bilimleri öğretmen adayları için STEM odaklı laboratuvar uygulamaları: "Sağlıklı Yaşam" etkinliği. International Journal of Humanities and Education, 4(9), 329-347.

Wendell, K. B. (2008). The theoretical and empirical basis for design-based science instruction for children. Unpublished Qualifying Paper, Tufts University.

West, M. (2012). STEM education and the workplace. Occasional Paper series, $4,4$.

Yasul, A. F., ve Samancı, O. (2015). Sınıf öğretmenlerinin 'grup çalışmaları'na ilişkin görüşlerinin incelenmesi. Igdir University Journal of Social Sciences, 7, 131-156.

Yıldırım, A., ve Şimşek, H. (2011). Sosyal bilimlerde nitel araştırma yöntemleri. (8. Bask1). Ankara: Seçkin Yayıncılık.

Yıldırım, B. (2013a, Kasım). STEM eğitimi ve Türkiye. IV. Ulusal ilköğretim bölümleri öğrenci kongresinde sunulmuş bildiri, Nevşehir Hacı Bektaşi Veli Üniversitesi, Nevşehir.

Yıldırım, B. (2013b, Eylül). Amerika, AB ülkeleri ve Türkiye' de STEM eğitimi. 22. Ulusal Ĕ̆itim Bilimleri Kurultayında sunulmuş bildiri, Eskişehir Osmangazi Üniversitesi, Eskişehir.

Yıldırım, B. (2016). 7. Sınıfen bilimleri dersine entegre edilmiş fen teknoloji mühendislik matematik (STEM) uygulamaları ve tam öğrenmeninetkilerinin incelenmesi. Gazi Üniversitesi, Eğitim Bilimleri Enstitüsü, Ankara.

Yıldırım, B., ve Altun, Y. (2015). STEM eğitim ve mühendislik uygulamalarının fen bilgisi laboratuar dersindeki etkilerinin incelenmesi. El-Cezeri Journal of Science and Engineering, 2(2), 28-44.

Yıldırım, P. (2017). Fen, teknoloji, mühendislik ve matematik (STEM) entegrasyonuna ilişkin nitel bir çalışma. Atatürk Üniversitesi Kazım Karabekir Ĕ̆itim Fakültesi Dergisi, 35, 31-55.

\section{Summary}

\section{Introduction}

STEM is an up-to-date educational approach that supports interdisciplinary work created by integrating science, mathematics, technology and engineering. STEM education involves learning engineering design and realizing that engineering is not just building things by providing students with applied engineering skills. In addition, STEM education covers the process of trying to teach science subjects or achievements with a practical activity by making use of mathematics and technology discipline (Hynes et al., 2011). There are many Engineering Design Process (EDP) models developed for the implementation of STEM education. One of these is the 9-step EDP model developed by Hynes et al. (2011). These stages are (1) introducing the problem, (2) determining the needs, (3) developing solution suggestions, (4) choosing the best solution, (5) making the prototype, (6) testing and evaluating the solution, (7) presenting the solution, (8) redesign and (9) completion of the design. When the studies in the literature on STEM education are examined, it is seen that there are many activities developed and implemented according to EDP (Aydin and Karsl1-Baydere, 2019; Eroğlu and Bektaş, 2016; Gökbayrak and Karışan, 2017; Karsl1-Baydere et al., 2019; 
Karslı-Baydere and Kurtoğlu, 2019; Tarkın- Çelikkıran and Aydın-Günbatar, 2017; Yildırım and Altun, 2015; Y1ldırım, 2017). However, no study has been found to develop a design to prevent tooth decay in the teaching of the topic "bacteria and dental health", which is one of the problems of our daily life and which concerns us all. In this context, it can be said that the study contributes to the literature.

The aim of this study is to examine the views of science teacher candidates about stem activity named" dental caries inhibitor", which was developed according to STEM education approach and applied to science teacher candidates.

\section{Method}

In this study, qualitative research method was used. The study group of the research consists of 7 science teacher candidates studying at a public university in the Eastern Black Sea region in the 2019-2020 academic year and taking the Science Teaching Laboratory Practices I course. The teacher candidates were divided into two groups, one of which is composed of three and the other is four. None of the teacher candidates who participated in the research have previously participated in an STEM event. In addition, pre-service teachers have experienced the subject of bacteria by making simple experiments related to protozoa in general biology lesson in the first year. The data of the study were collected through the semi-structured interview questions about the applications. Validity of semi-structured interview questions were ensured by consulting expert opinions. The implementation of the STEM activity was performed by the researchers. The researchers asked the science teacher candidates to read the problem scenario and enabled them to identify the problem. The science teacher candidates made research using smartphone, computer etc. to get the information they need for the problem. Teacher candidates were encouraged to develop solutions by thinking like an engineer. Later, they designed the product they want to develop by following the EDP steps on the activity sheet one by one. The science teacher candidates used another discipline of STEM education in their activities by using mathematical operations in determining the amount and price of the materials used in their designs. In this study, which requires an interdisciplinary study, the assistance of a faculty member working in the Department of Biology of the university was asked for in order to enable the science teacher candidates to test their designs. The researchers identified the bacteria that caused dental caries at the end of the literature review. Researchers preferred to use a type of bacteria that is the easiest to grow from these bacteria in the testing process and available in the university's existing laboratory. The aim is to achieve the same goal by minimizing the cost. At this stage, the science teacher candidates tested whether their products were successful in solving the problem by injecting their completed designs on bacterial strains. According to the test results, the design named "Çamsa" prepared by the first group is effective in reducing the bacteria that spreads in the mouth and cause tooth decay, whereas the "Solution" design of the second group was not effective. This STEM activity, which was implemented on Monday and Wednesday of the week, took a total of 4 weeks (8x50 minutes). After the STEM avtivity's implementation, the semi-structured interviews were conducted with each teacher candidate in an environment where the candidates felt comfortable related to the activity for 10-15 minutes. Content analysis method was used in the analysis of the semi-structured interview questions used within the scope of the research. 


\section{Results and Discussion}

When the findings obtained from the answers given by the science teacher candidates to interview questions are analyzed, it is seen that a total of five different themes were created in relation to the activity: "interesting sections in the activity", "challenged sections in the activity", "skills gained by the activity", "advantages of the activity" and "disadvantages of the activity" (See Table 1). In the research, it was concluded that STEM activity developed for bacteria and dental health increased the conceptual comprehension of science teacher candidates and contributed to the acquisition of some 21st century skills. In addition, although the teacher candidates mentioned some disadvantages related to the STEM activity in the research, it was concluded that the activity gave them mostly positive features such as increasing their motivation towards the lesson by providing a fun environment, enabling them to participate actively in the process and to be in a learning process by living.

\section{Pedagogical Implications}

In this study, a problem situation that prospective teachers encounter in daily life has been tried to be addressed. However, it was difficult for the researchers to obtain the microorganisms in the oral flora required for the test of the solution and to test the product developed by the teacher candidates. Based on this, it is recommended that researchers who will work with microorganisms should consider laboratory facilities. The dimension of mathematics in STEM activity developed and applied in this study was limited to proportionality operations and cost calculations. At this point, it is recommended that teachers or future researchers who will implement this activity should create a model for the enumeration of the nutrients to enrich the activity in terms of mathematics integration.

\section{Araştırmanın Etik İzinleri}

Yapılan bu çalışmada “Yükseköğretim Kurumları Bilimsel Araştırma ve Yayın Etiği Yönergesi" kapsamında uyulması belirtilen tüm kurallara uyulmuştur. Yönergenin ikinci bölümü olan "Bilimsel Araştırma ve Yayın Etiğine Aykırı Eylemler" başlığı altında belirtilen eylemlerden hiçbiri gerçekleştirilmemiştir.

Etik kurul izin bilgileri

Etik değerlendirmeyi yapan kurul ad1 =Giresun Üniversitesi Rektörlüğü Bilimsel Araştırma ve Yayın Etiği Kurulu

Etik değerlendirme kararının tarihi=21 Nisan 2020

Etik değerlendirme belgesi sayı numarası $=44079388-36$

\section{Yazar Bilgileri / Authors' Biodata}

Sena KURTOĞLU, Giresun Üniversitesi Eğitim Fakültesi Fen Bilgisi Öğretmenliği bölümünden mezun olmuştur. Giresun Üniversitesi Fen Bilgisi Eğitiminde yüksek lisans öğrencisidir.

Sena Kurtoğlu graduated from Giresun University, Faculty of Education, Department of Science Teaching. She is a master student in the Department of Science Education at Giresun University. 
Fethiye KARSLI BAYDERE, Giresun Üniversitesi Eğitim Fakültesinde Doçent Doktor olarak görev yapmaktadır. Çalışma alanları fen eğitimi, bilimsel süreç becerileri, bağlam temelli öğrenme ve STEM eğitimi yaklaşımıdır.

Fethiye Karslı Baydere works as an associate professor doctor at Giresun University, Faculty of Education. Her subjects are science education, scientific process skills, context-based learning and STEM education approach. 